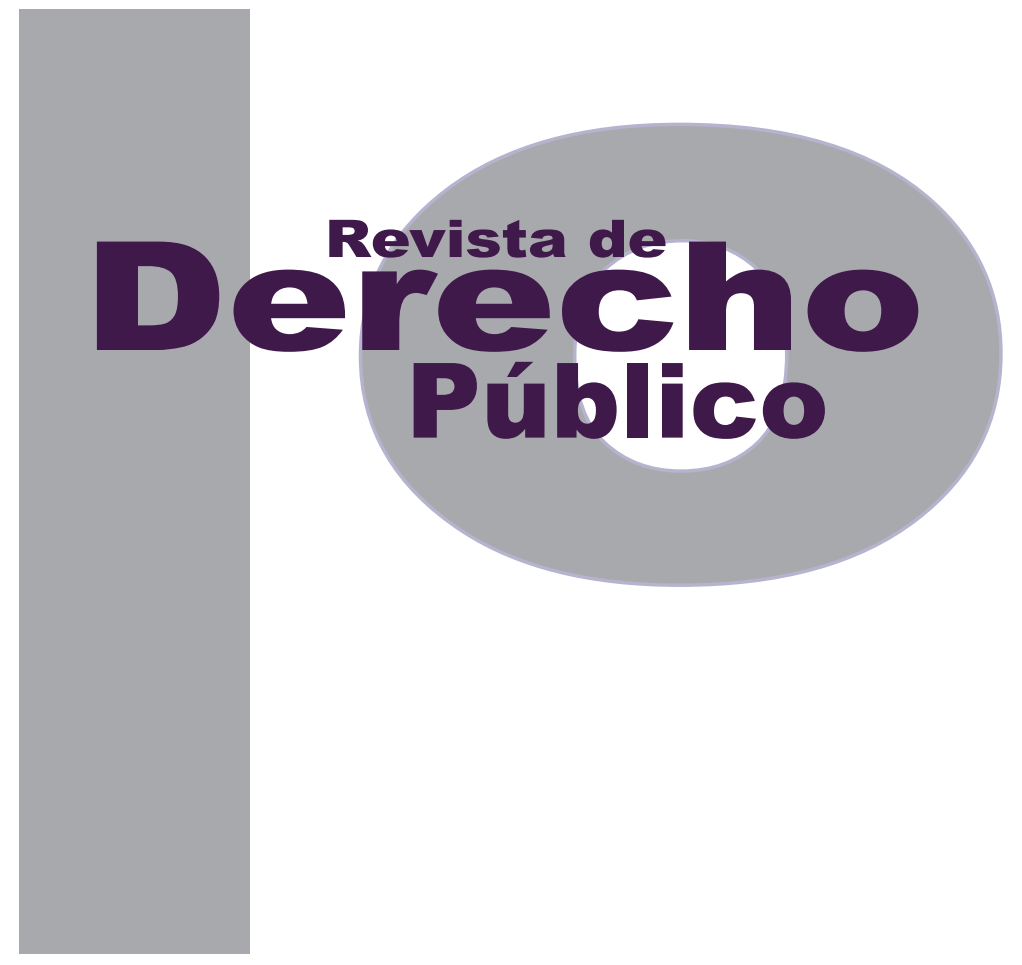

\title{
CuRso de Obligaciones II en la Facultad de DeRecho DE LA UNIVERSIDAD DE LOS ANDES: DE LA NORMA A LA PRÁCTICA
}

Marcela Castro R.

Universidad de los Andes

Facultad de Derecho

Revista de Derecho Público N. ${ }^{\circ} 32$

Enero - Junio de 2014. ISSN 1909-7778 


\title{
Curso de Obligaciones II en la Facultad de Derecho de la Universidad de los Andes: de la norma a la práctica*
}

\author{
Marcela Castro . $^{* *}$
}

\section{RESUMEN}

El aprendizaje autónomo por los estudiantes y no la transmisión de contenidos puntuales es lo que deben promover los docentes. En derecho, los contenidos mudan con frecuencia. La experiencia del curso Obligaciones II en la Facultad de Derecho de la Universidad de los Andes constituye un buen ejemplo de la forma como puede innovarse en la pedagogía de un curso básico, tradicionalmente magistral. La alineación de los objetivos, la metodología y las evaluaciones han permitido rediseñar el curso empleando distintas estrategias, donde los estudiantes son gestores de su formación y "aprenden a aprender" para desarrollar las competencias intelectuales y profesionales que necesita el futuro abogado. La tecnología ha sido una herramienta útil para
Autonomous learning by the students must be encouraged by teachers, rather than the transmission of specific contents. Legal contents are modified from time to time. The experience of the subject Obligaciones II in University of Los Andes Law School is a good example of how to innovate when teaching a traditional course. Lining up the objectives with the methodology used and the evaluation of the activities has allowed redesigning the subject with the use of different strategies, where the students are key managers of their education process and "Iearn to learn", while developing the necessary skills as future lawyers. Technology has been a useful tool but the proposal goes far beyond, rethinking the role of teachers and students.

Cómo citar este artículo: Castro, M. (Junio, 2014). Curso de Obligaciones II en la Facultad de Derecho de la Universidad de los Andes: de la norma a la práctica. Revista de Derecho Público, 32.

Profesora titular de la Facultad de Derecho de la Universidad de los Andes. Ganadora del Primer Premio de Innovación Docente, mayo de 2012. La autora agradece el apoyo del Programa Sócrates y del Centro de Investigación y Formación en Educación (CIFE) a sus actividades docentes. Así mismo, aprecia los comentarios y sugerencias de las profesoras Renata Amaya y Betsy Perafán, los cuales resultaron muy valiosos para la publicación de este escrito. 
el éxito de esta propuesta pero la innovación va mucho más allá, al reformular el rol del profesor y de los estudiantes.

PALABRAS ClaVE: aprendizaje autónomo, innovación pedagógica, aprendizaje basado en problemas (PBL), alineación curricular, docencia y TIC.
KEY WORDS: autonomous learning, teaching innovation, problem based learning (PBL), curricular lining up, teaching and technology. 


\section{SUMARIO}

Introducción - I. CARACTERÍSTICAS DEL CURSO DE OBLIGACIONES - II. INNOVACIONES PEDAGÓGICAS EN EL CURSO OBLIGACIONES II - III. PLANEACIÓN Y DISEÑO DE ACTIVIDADES - A. Primera parte del curso. Tema: responsabilidad civil. Descripción: juego de roles - B. Segunda parte del curso. Tema: prelación de créditos. Actividad: simulación de un proceso concursal de liquidación judicial - C. Actividad transversal: uso del hipertexto jurídico - IV. ALGUNOS RESULTADOS EN EL PROCESO DE APRENDIZAJE - V. REFLEXIÓN Y CONCLUSIONES - Bibliografía - Anexos. 
Introducción

Hace más de veinticinco años me dedico a la docencia en el Área de Derecho Privado, en la Facultad de Derecho de la Universidad de los Andes. He preferido dictar clases en el ciclo básico del pénsum pues considero que es allí donde mi aporte puede resultar más significativo en función de la formación de los futuros abogados. Pero a lo que he dedicado la mayor parte de mis esfuerzos en el terreno académico es a la enseñanza e investigación del Derecho de las Obligaciones, asignatura que tiene, sin duda alguna, una enorme importancia en la construcción de categorías jurídicas básicas que se emplearán en cursos más avanzados de la carrera -incluso en otras áreas del derechoy que serán de necesaria aplicación en el ejercicio profesional.

Además del estudio de múltiples elementos conceptuales que integran la materia, sus contenidos, su estructura, el vocabulario que le es propio, y de manera más relevante, los debates doctrinales y jurisprudenciales que enriquecen el derecho de las relaciones obligatorias, he estimado de gran importancia el conocimiento y aplicación de metodologías activas que estimulen la participación de los estudiantes en su proceso de aprendizaje. Mi inquietud relativa a la necesidad de dictar cursos de derecho de alta calidad, con apoyo en este tipo de metodología, se enmarca en la propuesta de la Facultad de Derecho de la Universidad de los Andes que, desde su fundación, ha promovido los enfoques pedagógicos novedosos, de forma tal que la misión de los profesores no consiste en transmitir conocimientos sino en crear condiciones que favorezcan un aprendizaje sólido, autónomo y constante por parte de los estudiantes. ${ }^{1}$

Según Fernández, "[I]os rasgos característicos de este nuevo modelo educativo exigen el desarrollo de un perfil profesional, de unos roles y unas actividades diferentes a las tradicionales en los estudiantes y los profesores. El perfil apropiado del estudiante viene caracterizado por los siguientes elementos: aprendiz activo, autónomo, estratégico, reflexivo, cooperativo, responsable" 2 .

El Programa Sócrates, y más recientemente el Centro de Investigación y Formación en Educación (CIFE) de la Universidad, son referentes necesarios en el proyecto educativo de la Facultad, por cuanto han asumido el liderazgo en la tarea de consolidar un cuerpo profesoral que, al lado de su experticia en las respectivas áreas de conocimiento, avance en forma decidida hacia el mejoramiento de las herramientas metodológicas que fortalezcan el proceso de enseñanzaaprendizaje.

En este artículo presentaré en forma resumida mi experiencia como profesora en el curso Obligaciones II, en la Facultad de Derecho de la Universidad de los Andes. En particular, haré

Véase OTERO CLEVES, Ana María y JIMÉNEZ ÁNGEL, Andrés. Cuarenta años innovando el derecho: una mirada a la Facultad de Derecho de la Universidad de los Andes. Bogotá: Universidad de los Andes, Facultad de Derecho, 2010. Pp. 45 y ss.

2 FERNÁNDEZ MARCH, Amparo. Metodologías activas para formar en competencias [en línea]. Pp. 36 y ss. Disponible en: http://revistas. um.es/index.php/educatio/article/viewFile/152/135 
referencia a algunas reformas pedagógicas que he introducido en los años recientes, las cuales apuntan a una formación más rigurosa en esta disciplina. Con estas innovaciones he intentado mejorar la calidad de la enseñanza-aprendizaje, procurando a la vez una coherencia real entre los objetivos perseguidos, las actividades planeadas y las evaluaciones realizadas.

\section{CARACTERÍSTICAS DEL CURSO DE OBLIGACIONES}

Sin excepción, la asignatura de Obligaciones se encuentra en el corazón del pénsum de las facultades de Derecho y se le otorga una importancia especial en la formación de los estudiantes. Ello ha sido así desde la fundación de las primeras facultades, en consideración a su carácter técnico y a sus contenidos abstractos, que sientan muchas de las bases para la comprensión de la ciencia jurídica. Si bien sus conceptos han sido elaborados y desarrollados desde el derecho privado, el régimen de las obligaciones contribuye a la solución de problemas en otras ramas del derecho. Así mismo, como parte esencial del "derecho común" de las relaciones jurídicas interpersonales con contenido patrimonial, contiene reglas y mecanismos útiles para la interpretación de las normas y la integración de negocios jurídicos pertenecientes a cualquier especialidad.

Debe mencionarse que, de tiempo atrás, todo el derecho privado viene recibiendo un importante acervo de principios y valores propios del Estado social de derecho, que ha generado el fenó- meno de su constitucionalización ${ }^{3}$, el cual ha influido de manera notable en la aplicación de las leyes civiles y la solución de problemas surgidos en actos jurídicos celebrados entre particulares. Aun así, una característica importante del régimen de las obligaciones es su carácter técnico, dogmático y la marcada estabilidad en sus contenidos, de manera que estos han permanecido relativamente fijos por mucho tiempo en la mente de los juristas, con muy pocas modificaciones temáticas.

La enseñanza del derecho de las obligaciones ha sido una constante en las facultades de Derecho en los países de tradición continental, desde la fundación de las universidades en la Europa medieval. En el siglo XI nació la Universidad de Bolonia, en la cual los maestros transmitían a sus alumnos las siete artes liberales ${ }^{4}$ que cimentaban la educación profesional avanzada. En esta formación sobresalió el derecho como uno de los saberes fundamentales, siendo la de Bolonia la universidad más destacada en el estudio de la ciencia jurídica a través del derecho romano y del derecho canónico.

La Escuela de Bolonia, especialmente con los glosadores, influyó decisivamente en el denominado "renacimiento jurídico medieval" el cual rescató y divulgó el Corpus luris Civilis, obra justinianea que propició la recepción del derecho

3 CALDERÓN VILLEGAS, Juan Jacobo. La constitucionalización del derecho privado en Colombia: la verdadera historia del impacto constitucional en Colombia. Bogotá: Universidad de los Andes, Universidad del Rosario, Temis, 2011.

Trívium: gramática, retórica y dialéctica; quadrívium: aritmética, geometría, astronomía y música. 
romano y en particular su régimen de obligaciones en toda Europa y con él sentó las bases de los sistemas jurídicos modernos. “(...) descubiertas las Pandectas, los juristas de la Edad Media pudieron encontrar en el Derecho Romano todo un sistema de principios generales aptos para la elaboración de los nuevos ordenamientos" 5 .

Desde entonces, la enseñanza del derecho de las obligaciones ha sido un elemento común en los diseños curriculares de las facultades de Derecho hasta nuestros días. Se trata de una asignatura extensa y compleja que siempre ha tenido un "público cautivo", por lo cual los profesores de la materia contamos con una audiencia segura y quizás ello nos sustrae -a veces demasiado- de las preocupaciones que nos agobian cuando debemos esforzarnos en diseñar, en forma muy cuidadosa, un curso nuevo para darle un atractivo especial de manera que los estudiantes se sientan persuadidos y no solo obligados a inscribirse.

La docencia en este campo ha estado marcada por una metodología tradicional de cátedra magistral: el profesor diserta sobre los grandes misterios del derecho de las obligaciones, incursionando en la interpretación del Código civil (decimonónico además), con apoyo en las reglas jurisprudenciales salpicadas de viejos latinajos, la doctrina autorizada y, con suerte, en algunos elementos de derecho comparado.

5 DUPLÁ MARÍN, Teresa. La recepción del derecho romano en el movimiento de unificación del derecho privado y la constitución europea [en línea]. Disponible en: http://ruc.udc.es/dspace/bitstream/2183/2225/1/ AD-7-14.pdf. La autora cita a Kunkel, historiador del derecho romano, quien sostiene que al igual que la Biblia para los teólogos, el Corpus luris era para los juristas de la Edad Media, la última palabra de la sabiduría.
Los estudiantes, por su parte, tratan de capturar y retener la mayor cantidad de información posible sustentados en sus propias anotaciones de clase, en la lectura de los autores clásicos -sobre todo franceses, chilenos y colombianos cuando ello es exigido por el profesor o la profesora-y, especialmente, en la memoria.

Con este panorama, y a pesar de que los profesores podemos sentirnos tentados por la idea de "lucirnos" con un despliegue de conceptos y teorías sobre obligaciones, cayendo en la rutina pedagógica que desmotiva a docentes y estudiantes, siempre he considerado un reto mayor la elaboración del programa de clases para cada semestre. Con ello en mente, me esfuerzo para que el programa no solo se mantenga permanentemente actualizado, sino que se desarrolle con metodologías activas que involucren de manera decidida al estudiante en su propio aprendizaje, permitiéndole integrar nuevo conocimiento a los conceptos que ya tiene ${ }^{6}$.

En la estructura actual del pénsum, la materia en cuestión tiene cinco créditos, un alto valor en términos relativos frente a otras materias del pregrado que generalmente tienen tres o cuatro. Las clases presenciales se realizan dos veces por semana, con duración de una hora y cincuenta minutos cada una. El número de créditos significa que por cada hora presencial de clase, los estudiantes deben dedicar cinco horas de preparación, lo cual eleva la exigencia tanto para los estudiantes como para el (la) profesor(a), y a

6 Enfoque constructivista. POSNER, George. Análisis del currículo. Miguel Ángel Martínez (tr.). $3^{a}$ ed. México: McGraw Hill, 2005. P. 68. 
la vez es una oportunidad para sacar provecho de un buen número de horas disponibles para hacer realidad lo que se enuncia en el programa. Esta elevada intensidad horaria requiere un cuidadoso diseño para las actividades que deben realizarse de manera presencial y aquellas que se ejecutan por fuera de clase, en orden a la lectura de materiales y la preparación de trabajos individuales y en grupo.

Un aspecto importante ha sido la clasificación de Obligaciones II como un curso PBL, por parte de la Facultad de Derecho, es decir, que se desarrolla en un altísimo porcentaje con énfasis en el aprendizaje basado en la resolución de problemas ${ }^{7}$. Esta categorización es favorable para introducir innovaciones pedagógicas, puesto que cada sección del curso tiene un máximo de 22 estudiantes, y permite una mayor interacción profesor(a)-estudiantes y entre los alumnos como pares en un aprendizaje colaborativo ${ }^{8}$. Claramente, experimentar con metodologías que tienen alta exigencia de participación en cursos grandes (23 personas o más) resulta más arriesgado y complejo.

\section{INNOVACIONES PEDAGÓGICAS EN EL CURSO OBLIGACIONES II}

En los últimos años ha adquirido mucha fuerza la idea de innovar en mi curso de Obligaciones. Después de enseñar el tema por más de dos dé-

7 Problem based learning; en español Aprendizaje basado en problemas. Véase, POSNER. Ob. cit. P. 48.

8 Sobre aprendizaje cooperativo véase Fernández. Ob. cit. P. 45. cadas, no me he resignado a la cómoda postura de mantener un programa estático, con sus contenidos estables y una metodología que, si bien ha sido predominantemente activa, no se encontraba satisfactoriamente alineada con los objetivos propuestos y con los mecanismos de evaluación.

En esa dirección, para mí han sido fuente de inspiración dos aspectos debatidos en encuentros pedagógicos recientes organizados por el Programa Sócrates. Por un lado, el "Pénsum vivo", que me ha hecho reflexionar sobre la distancia que muchas veces existe -pero que no debería existir - entre los objetivos, las actividades y las formas de evaluación que contiene el programa del curso y lo que sucede en la realidad, en el salón de clase. En otras palabras, hay una creencia errónea en que la elaboración del "programa" es una obligación que el profesor cumple a cabalidad cuando entrega a sus estudiantes, el primer día de clases un documento que incluye objetivos, contenidos, lecturas, fechas de exámenes y algunas reglas del juego, y que parecería suficiente para guiar sin tropiezos el proceso de enseñanza-aprendizaje durante el semestre. Sin embargo, a mí me ha sucedido -y he visto que a otros colegas también- que esa declaración de buenas intenciones se queda muchas veces en el papel, que lo aguanta todo, divorciado de lo que ocurre en el salón de clases y en los espacios en que los estudiantes deben trabajar por su cuenta. Por ello, estimé de la mayor relevancia asegurarme que el programa no sea solo una bitácora del curso sino

También llamado currículo operativo. POSNER. Ob. cit. P. 13. 
una oportunidad para revisar constantemente mi práctica docente, para ojalá lograr que sus enunciados se vivan efectivamente en las sesiones presenciales y en las actividades del curso que los estudiantes realizan individualmente $o$ en grupo, fuera del aula.

Por otro lado, en algunas reuniones de pedagogía promovidas por el Programa Sócrates y el CIFE, se ha planteado la necesidad inaplazable de que los (las) profesores (as) definamos rigurosamente los objetivos de cada asignatura y los alineemos con la metodología y las evaluaciones del respectivo curso. Reitero: esto debemos hacerlo en función de las competencias que la materia se propone desarrollar en los estudiantes, de suerte que haya coherencia entre lo que el curso se propone, las actividades que el profesor diseña y la metodología que utiliza para lograrlo.

Según el CIFE, “[e]xisten maneras muy distintas de expresar los objetivos de los cursos y programas y, en consecuencia, lo que se busca evaluar como resultado de los mismos. El formato más generalizado es el de los objetivos de aprendizaje expresados en forma de conductas o acciones concretas. Estas conductas a su vez, han sido organizadas en taxonomías, algunas de las cuales organizan los objetivos en términos de habilidades cognitivas básicas o de nivel inferior (conocer, recordar, entender, aplicar) y habilidades cognitivas de nivel superior (analizar, sintetizar, evaluar)"10.

10 CIFE. Sistema de evaluación de la efectividad de los programas educativos de la Universidad de los Andes. Bogotá: Autor. 2010. P. 7. El documento cita la taxonomía de Bloom (1969).
Como un segundo paso, esta alineación debe lograrse, así mismo, con los objetivos generales de la Facultad de Derecho. Estos objetivos integran tres dimensiones complementarias para los estudiantes en el nivel de pregrado: ${ }^{11}$

- Competencias cognitivas: pensar como abogados.

- Competencias prácticas: actuar como abogados, $y$

- Valores y actitudes de la profesión: ser abogados.

Las competencias profesionales que se han definido específicamente para el pregrado en la Facultad de Derecho, en términos de lo que los egresados del programa deben estar en capacidad de hacer, son las siguientes:

(i) Investigación jurídica ${ }^{12}$, que comprende:

- Enfrentar retos de aprendizaje de forma autónoma;

- Buscar y obtener información pertinente y suficiente a partir de diferentes métodos, logrando sistematizarla y analizarla con fines de descripción, crítica y aplicación; así mismo para contribuir a la creación de nuevo conocimiento;

11 CIFE. Competencias profesionales de los programas de Derecho. Bogotá: Universidad de los Andes, 2012.

12 En el pregrado esta competencia se puede resumir como "aprender a aprender", que potencia la autonomía del estudiante en su proceso de formación. 
- Elaborar y desarrollar proyectos de investigación; e

- Integrar las diferentes áreas del derecho y aproximarse a este y a la realidad social desde diversas perspectivas del conocimiento

(ii) Prevención y resolución de conflictos, competencia que cubre los siguientes aspectos:

- Identificar, formular y resolver problemas jurídicos de forma teórica y práctica;

- Evaluar los posibles mecanismos de manejo del conflicto, generar estrategias alternativas y recomendar la que se considere más adecuada para el caso concreto; y

- Formular y ejecutar un plan de acción que se derive de los anteriores pasos.

(iii) Comunicación y argumentación, con los siguientes componentes:

- Formular esquemas argumentativos sólidos y convincentes;

- Escoger estrategias argumentativas a partir de la definición del auditorio y del rol del orador;

- Utilizar eficazmente métodos de comunicación oral y escrita en un lenguaje técnico adecuado al destinatario; y

- Reconocer y comprender los diferentes puntos de vista y estar en capacidad de integrarlos en la estrategia argumentativa.
Como competencia transversal se identificó la de comprender y aplicar contenidos específicos a casos y situaciones problemáticas que atañen al derecho.

Se nos ha explicado, con razón, que no es realista pretender que una materia intente desarrollar a la vez todas las competencias profesionales. Así, algunas harán énfasis en comprender, otras en aplicar, otras en analizar. El pénsum debe ofrecer materias que, en conjunto y de manera coordinada, apunten al desarrollo de una o más habilidades que, sumadas, permitan la formación integral del futuro abogado.

Pero en este contexto pedagógico, ¿qué significa para mí innovar? y ¿por qué es inaplazable innovar?

Como ya lo mencioné, la fijación de objetivos de aprendizaje no debe ser un mero enunciado formal, sin contenido real. Su formulación por el profesor debe realizarse en forma cuidadosa, teniendo en cuenta el tipo de curso (ej.: de teoría o práctica; de derecho sustantivo o de procedimiento; del ciclo de contextualización, del básico o de profundización, etc.) e implica un compromiso cuyo cumplimiento efectivo debe verificarse con el desarrollo de competencias intelectuales y profesionales por parte de los estudiantes.

La innovación a la que me refiero comprende el uso de tecnologías de la información y la comunicación (TIC), pero innovar en pedagogía no es sinónimo de ni se limita al empleo de computadores, software educativo, ambientes virtuales 
de aprendizaje (AVA), etc. Va mucho más allá. De hecho, la Universidad de los Andes se ha comprometido institucionalmente a apoyar los procesos de docencia e investigación con el empleo de recursos tecnológicos ${ }^{13}$ y ha consagrado ingentes recursos para cumplir este propósito. Los profesores y estudiantes tenemos a disposición valiosas herramientas para desarrollar nuestras actividades académicas: aulas virtuales, recursos bibliográficos, hardware y software para uso en clase y response cards, entre muchos otros. Personalmente, he encontrado en la tecnología una gran aliada no solo por su atractivo para estudiantes de 19 o 20 años, sino porque ha probado ser útil y eficaz, en cuanto me ha brindado múltiples y versátiles alternativas para diseñar las actividades del curso. Sin embargo, la tecnología no es, per se, sinónimo de innovación pedagógica ni es su componente único o el más importante.

En suma, la tecnología es un medio pero no un fin es sí mismo. La innovación debe servir al propósito de enriquecer y profundizar la experiencia educativa. Además, como lo enseña el sentido común, innovar debe ser un proceso permanente. Nuestras más atrevidas propuestas pedagógicas pueden ser obsoletas al poco tiempo. No habrá nunca un producto acabado; siempre será necesario que el profesor esté pensando en función de mejorar su programa, afinar sus objetivos, diseñar mejor sus actividades, emplear en forma más efectiva el tiempo y

13 Véase el Programa de Desarrollo Integral (PDI) de la Universidad de los Andes. El PDI plantea como uno de los objetivos institucionales articular efectivamente los recursos tecnológicos con los procesos misionales, estratégicos y de apoyo (punto 7.2). los recursos tecnológicos, con miras a potencializar al máximo las capacidades, talentos y competencias de los estudiantes.

En particular, estoy convencida de que innovar en Obligaciones II me ha exigido repensar, reinventar el curso, desde los objetivos de enseñanza. He trabajado en el diseño de una asignatura con una metodología en la que los estudiantes se involucren frontalmente en su propio aprendizaje. He comprobado que este tipo de medidas fomentan una formación básica de mejor calidad, que sintoniza a los estudiantes con las ideas fundamentales del derecho privado y las relaciona con lo que sucede en la vida real.

Según indiqué previamente, la asignatura "Obligaciones" es extensa y comprende una cantidad considerable de categorías conceptuales e instituciones jurídicas. Para sintetizar, la materia se divide en seis grandes temas:

(i) Concepto de obligación.

(ii) Clasificación de las obligaciones y régimen de cada clase.

(iii) Fuentes de las obligaciones.

(iv)Efectos de las obligaciones.

(v) Transmisión de las obligaciones.

(vi) Extinción de las obligaciones.

En la Universidad de los Andes el curso se divide en dos semestres. Obligaciones I se concentra en el estudio del concepto de obligación, sus 
clases y, en cuanto a fuentes, examina la fuente voluntaria (contrato y declaraciones de voluntad en general), la fuente legal y el enriquecimiento sin causa. Por su parte, Obligaciones II se dedica al estudio del hecho ilícito como fuente de obligaciones, a los efectos, transmisión y extinción de las obligaciones ${ }^{14}$.

En concreto, Obligaciones II se ubica en el cuarto semestre del pénsum de pregrado, que corresponde al ciclo básico de la carrera. Su diseño requiere un delicado balance entre lo conceptual y lo práctico, entre lo sustantivo y lo procedimental. Es una materia formativa con notable incidencia en el ejercicio práctico de la profesión de abogado. De ahí el título de esta experiencia pedagógica: “De la norma a la práctica.” En consecuencia, la formulación de objetivos debe estar acorde con las competencias que esta asignatura está llamada a desarrollar. En el ejercicio de alineación debe haber correspondencia entre los objetivos formulados, las actividades que se diseñen para ser realizadas dentro y fuera del aula y la metodología empleada. Esta alineación no significa de ninguna manera descuidar o menospreciar los contenidos de la materia frente a los aspectos pedagógicos. Dichas actividades se justifican en la medida en que sirvan para afianzar los conocimientos jurídicos de los estudiantes, y que estos se apropien de la disciplina con rigor intelectual en sus aspectos teóricos, prácticos y éticos.

Teniendo en cuenta los objetivos que el grupo de profesores hemos definido para los cursos

14 Anexo 1. Programa del curso Obligaciones II. de Obligaciones (I y II), hemos señalado cuáles son las competencias profesionales que pretendemos desarrollar en los estudiantes. Ello nos impuso la necesidad de diseñar actividades diversas que sean coherentes con los objetivos específicos que nos hemos propuesto. Además, la variedad en lo que deben "hacer" los estudiantes ayuda a alejar la rutina y el desaliento que a veces los embarga.

Al finalizar los dos cursos de Obligaciones, el estudiante debe estar en capacidad de:

- Identificar la estructura y el régimen de las obligaciones, a saber: su concepto y clases, sus fuentes, sus efectos, su transmisión y su extinción valorando su importancia en el derecho privado (civil y comercial) y en el sistema jurídico en general;

- Comprender los conceptos fundamentales, las instituciones, principios y reglas básicas del derecho de las obligaciones al punto de poder relacionarlos entre sí y aplicarlos a situaciones fácticas;

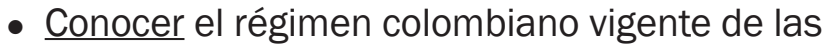
obligaciones a través del análisis de las normas, la doctrina y la jurisprudencia relevantes;

- Integrar elementos de teoría y práctica en el estudio de las obligaciones, así como los aspectos sustantivos y procedimentales involucrados;

- Desarrollar destrezas/habilidades básicas para resolver problemas en el campo de las obligaciones; 
- Conocer con suficiencia el vocabulario jurídico propio del derecho de las obligaciones, de manera que se utilice adecuada y rigurosamente en presentaciones orales y escritas.

El cumplimiento de los objetivos requiere que los estudiantes abandonen su actitud de receptores pasivos de una información valiosa que les transmite el profesor. Para que los propósitos pedagógicos sean una realidad, se requiere que los alumnos "hagan cosas" específicas durante el semestre: por ejemplo, el conocer o comprender un concepto debe materializarse en que pueda analizarlo, distinguirlo de otros conceptos, ejemplificarlo o aplicarlo. Por esa razón, los enunciados generales sobre lo que el curso pretende, sin particularizar aquello que los alumnos deben estar en capacidad de hacer cuando lo han finalizado con éxito, no constituye una definición adecuada de objetivos, pues no permite identificar las competencias que han de desarrollarse, ni planear la manera como ello ha de lograrse; tampoco permite evaluar si en efecto aquellos se cumplieron.

La evaluación de los estudiantes durante el curso también transforma su función: pasa de ser una actividad mecánica encaminada a cumplir una exigencia de la Universidad (entregar notas) a una instancia necesaria para verificar si la propuesta pedagógica del profesor se ha cumplido a la luz de los objetivos propuestos. Para el diseño de estas evaluaciones también he pensado en distintas estrategias y mecanismos, teniendo en mente las diferentes habilidades intelectuales y profesionales que se busca privilegiar. Unas son individuales y otras en grupo; unas escritas y otras orales (en particular el examen final); algunas presenciales, otras empleando herramientas tecnológicas y virtuales.

Para el seguimiento del desempeño de los estudiantes es indispensable la idea de "evaluación auténtica", es decir, enfrentarlos a situaciones que sean usuales en el ejercicio de la profesión y que les exija pensar y actuar como abogados. Este tipo de evaluación los prepara para enfrentar los retos que encontrarán en sus actividades futuras y sitúan el aprendizaje en un contexto concreto y no como un saber en abstracto ${ }^{15}$. En Obligaciones II es propicia la utilización de simulaciones y ejercicios alrededor de hipótesis fácticas que sean parecidas a la vida real, tanto como sea posible, puesto que se trata de una disciplina jurídica con vocación de ejercicio práctico.

\section{PLANEACIÓN Y DISEÑO DE ACTIVIDADES}

Teniendo en cuenta los objetivos arriba señalados he diseñado varias actividades que propugnan por una evaluación auténtica, tareas con las que pretendo fomentar el aprendizaje autónomo pero colaborativo de los estudiantes y que a la vez se satisfagan los objetivos enunciados en el programa de Obligaciones II. A continuación presentaré, a título ilustrativo, tres estrategias que he aplicado en los más recientes semestres.

15 CIFE. Ob. cit. P. 9. 


\section{A. Primera parte del curso. Tema: responsabilidad civil. Descripción: juego de roles}

Los estudiantes han examinado los conceptos centrales del hecho ilícito como fuente de obligaciones, con base en las normas, la lectura de doctrina y ejercicios de análisis de jurisprudencia seleccionada. En clase, también se han trabajado hipótesis que permiten identificar los elementos de la responsabilidad civil contractual y extracontractual. Con el juego de roles Ilega el momento de verificar si los han comprendido al punto de aplicar esos conceptos a una situación problemática (PBL 1).

Los objetivos de este ejercicio son: desarrollar habilidades para la resolución de problemas jurídicos y conocer con suficiencia el vocabulario jurídico propio del derecho de las obligaciones, de manera que se utilice adecuada y rigurosamente en presentaciones orales y escritas" (ver $5^{\mathrm{a}}$ y $6^{\mathrm{a}}$ viñetas, en objetivos del curso Obligaciones). El juego de roles se ha diseñado como un proceso arbitral en el cual todos los estudiantes asumen un papel relevante. Para ello, la clase se divide en tres: (i) abogados parte demandante; (ii) abogados parte demandada, y (iii) tribunal de arbitramento. Los estudiantes escogen con quiénes van a integrar el grupo y la profesora asigna los roles al azar, luego de la primera sesión del ejercicio, como se explica más adelante.

Cada semestre se elabora un problema enfocado en la responsabilidad civil (RC), en cuyos hechos pueden encontrarse supuestos de RC con- tractual, extracontractual o ambos. Se incluyen datos que pueden apoyar la argumentación de la parte demandante y otros que pueden favorecer a la parte demandada ${ }^{16}$.

El ejercicio se desarrolla en seis sesiones consecutivas, pero la actividad de juego de roles no cubre sino una porción de la clase para poder avanzar en otros temas. En la primera sesión de este ejercicio, antes de que los estudiantes conozcan su rol, se da a conocer el problema y se trabaja con la metodología PBL. Se identifican en el grupo los hechos del caso, las instituciones jurídicas involucradas, se formulan los problemas jurídicos y se acuerdan las metas de aprendizaje. En esta sesión, en forma colaborativa, y con preguntas de la profesora, los estudiantes visualizan la responsabilidad civil como una institución jurídica compleja y se concientizan de hasta dónde llega su conocimiento previo, y a partir de dónde deben indagar para aprender, de manera autónoma, lo que no conocen (metas de aprendizaje). El problema planteado es un buen pretexto para avanzar y profundizar en el conocimiento del sistema de la responsabilidad civil. Junto con el problema, la profesora da a conocer los criterios de evaluación de cada uno de los trabajos que los grupos deben elaborar y de las actuaciones que van a realizar; en total son seis matrices, como se detalla posteriormente.

Luego de asignar los roles, en la segunda sesión los demandantes deben presentar, en máximo dos páginas, un esquema de su demanda: sín-

16 Ver, por ejemplo, el problema “Un viaje sin regreso”. Anexo 2. 
tesis de los hechos relevantes, lo que pretenden y los fundamentos de derecho que invocan ${ }^{17}$. Dos representantes del grupo, designados por este, presentan oralmente su esquema (máximo diez minutos) y el grupo debe cargar en sicuat el documento para el conocimiento de todos. A este trabajo corresponde el formato 1 de la matriz de evaluación, llamado "Esquema parte demandante" 18 .

En la tercera sesión, los demandados deben presentar un esquema de su contestación a la demanda: lo que responden a los hechos, sus defensas (excepciones) y los fundamentos jurídicos que invocan ${ }^{19}$. De forma análoga a lo ya explicado en el párrafo anterior, dos representantes del grupo, designados por este, presentan oralmente su esquema (máximo diez minutos) y el grupo debe cargar en sicua+ el documento para el conocimiento de todos. A la elaboración de este esquema y su presentación se refiere el formato 2 de la matriz de evaluación de la parte demandada ${ }^{20}$.

En la cuarta sesión, el tribunal arbitral debe proferir un "acta de misión", en la cual analiza en forma preliminar su competencia para conocer el caso, fija el alcance del litigio y formula los

17 En este juego de roles, por los objetivos de derecho sustantivo que persigue, no se exige el cumplimiento riguroso de los requisitos de una demanda previstos en el Código de Procedimiento Civil.

18 Ver anexo 3: matriz de evaluación esquema parte demandante.

19 En este juego de roles, por los objetivos de derecho sustantivo que persigue, no se exige el cumplimiento riguroso de los requisitos de una contestación de demanda, previstos en el Código de Procedimiento Civil. problemas jurídicos que debe resolver en el laudo. Dos representantes del panel arbitral, designados por el grupo de árbitros, deben presentar oralmente el acta de misión en diez minutos y cargar en sicua+ el documento para el conocimiento de todos. Véase el formato 3 de la matriz de evaluación ${ }^{21}$.

En la quinta sesión, las partes acuden a presentar ante el tribunal sus alegatos de conclusión, oralmente (veinte minutos cada una, con cinco minutos para rebatir al contrario) y por escrito, estos últimos se cargan en sicua+. Aquí dos representantes de cada parte profundizan en el análisis de los puntos de derecho y argumentan su posición con apoyo en las fuentes jurídicas aplicables (normas, jurisprudencia, doctrina). La profesora evalúa esta actividad según los criterios previstos en los formatos 4 y 5 de la matriz de evaluación ${ }^{22}$.

Finalmente, en la sexta sesión, el tribunal de arbitramento profiere el laudo mediante el cual resuelve definitivamente la controversia. El documento, que debe tener en cuenta los alegatos de las partes y la propia investigación del tribunal, se carga en sicua + y se presenta oralmente en audiencia (veinte minutos más diez minutos para resolver preguntas de aclaración formuladas por las partes). El laudo se califica conforme con el formato 6 de la matriz de evaluación ${ }^{23}$.

21 Ver anexo 5: matriz de evaluación-Acta de misión tribunal arbitral.

22 Ver anexos 6 y 7: matrices de evaluación alegatos de conclusión parte demandante y parte demandada.

23 Ver anexo 8: matriz de evaluación laudo arbitral. 
Durante las seis sesiones los estudiantes toman la palabra y la profesora dirige la actividad, haciendo preguntas, verificando que los conceptos se comprendan cabalmente, que no se omita información importante, que se utilice correctamente el vocabulario jurídico y que se respete el uso de la palabra y el tiempo asignado. Fuera de las sesiones de clase, los grupos deben organizar internamente su trabajo, investigar las fuentes, redactar los documentos y planear la exposición oral.

Terminada la actividad, la profesora retroalimenta al grupo con observaciones generales que sirven de cierre al módulo de responsabilidad civil.

\section{B. Segunda parte del curso. Tema: prelación de créditos. Actividad: simulación de un proceso concursal de liquidación judicial}

En el módulo sobre "efectos de las obligaciones" se estudia el patrimonio como prenda general de los acreedores y las acciones que estos pueden ejercer para la satisfacción de su crédito. El objetivo del ejercicio de simulación es que los estudiantes apliquen, en una situación concreta, los conceptos relacionados con la prelación de créditos y, de paso, conozcan los principales aspectos procedimentales de un proceso de liquidación (antes denominado concurso de acreedores o quiebra). Esta actividad tiende a desarrollar tres objetivos de la materia, enunciados como: "comprender los conceptos fundamentales, las instituciones, principios y reglas básicas del derecho de las obligaciones al punto de poder relacionarlos entre sí y apli- carlos a situaciones fácticas"; "integrar elementos de teoría y práctica en el estudio de las obligaciones, así como los aspectos sustantivos y procedimentales involucrados", y "conocer con suficiencia el vocabulario jurídico propio del derecho de las obligaciones, de manera que se utilice adecuada y rigurosamente en presentaciones orales y escritas." (Véanse las viñetas 2, 3 y 6 en la lista de objetivos del curso).

Para esta actividad, cada semestre se plantea un caso de una sociedad comercial que, tras una serie de dificultades económicas, entra en un proceso de liquidación judicial al que deben acudir sus acreedores. Para ilustrar la situación fáctica, con la ayuda del laboratorio LIDIE de la Universidad, se han elaborado varias historietas animadas que narran cómo la persona jurídica termina siendo sujeto de un proceso concursal. Las escenas de estas historias se alojan en sicua+ para ser consultadas por los estudiantes como una información previa y necesaria para la comprensión del contexto dentro del cual se produce la cesación de pagos, la cual da lugar a la aplicación de las normas sobre insolvencia empresarial. En este escrito muestro escenas del caso Creaciones Modernas Ltda*.

\footnotetext{
Las imágenes y gráficos que siguen a continuación tienen como fuente: Curso obligaciones II, Marcela Castro, elaborado por el Laboratorio de Investigación y Desarrollo sobre Informática y Educación, LIDIE, Universidad de los Andes.
} 

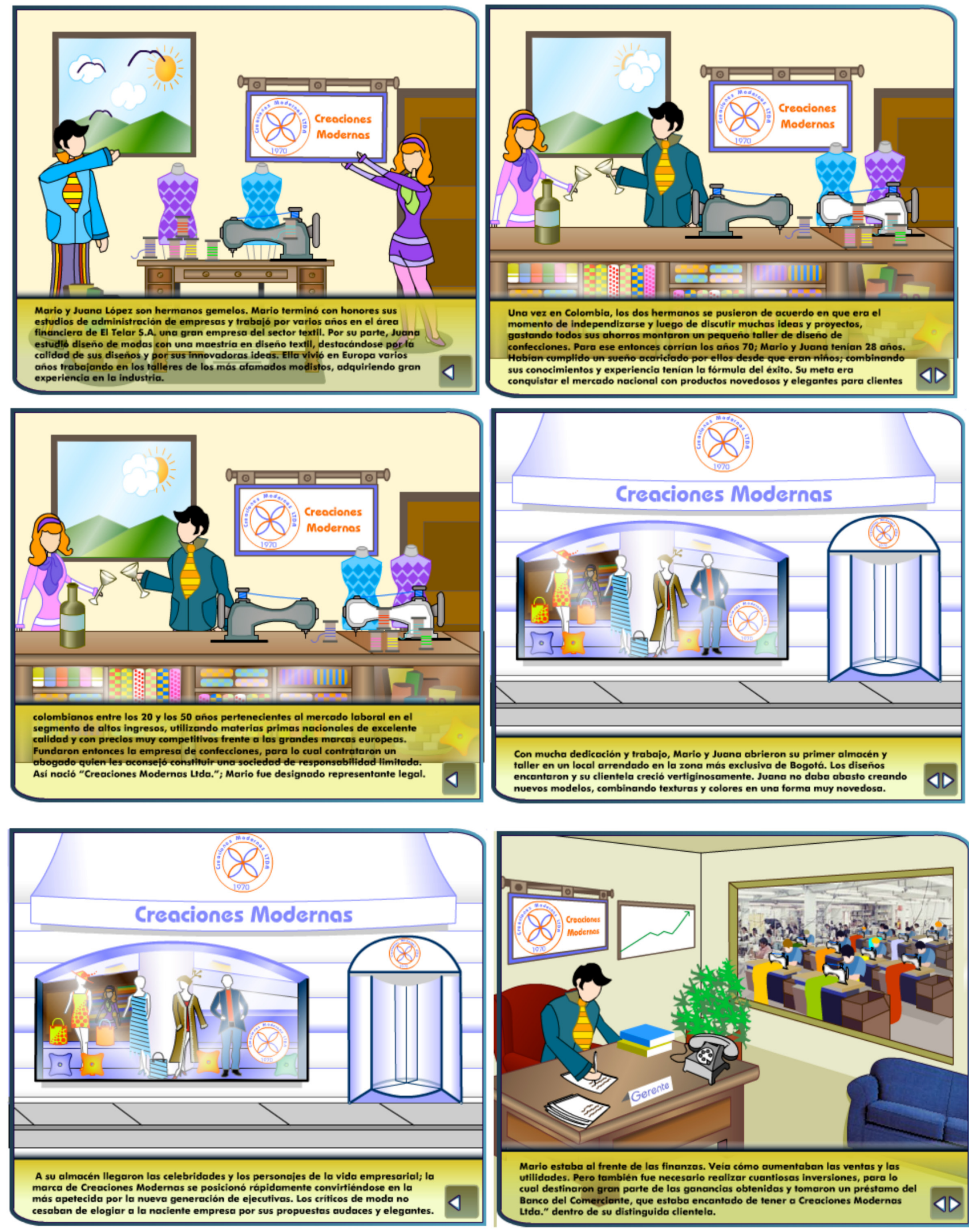

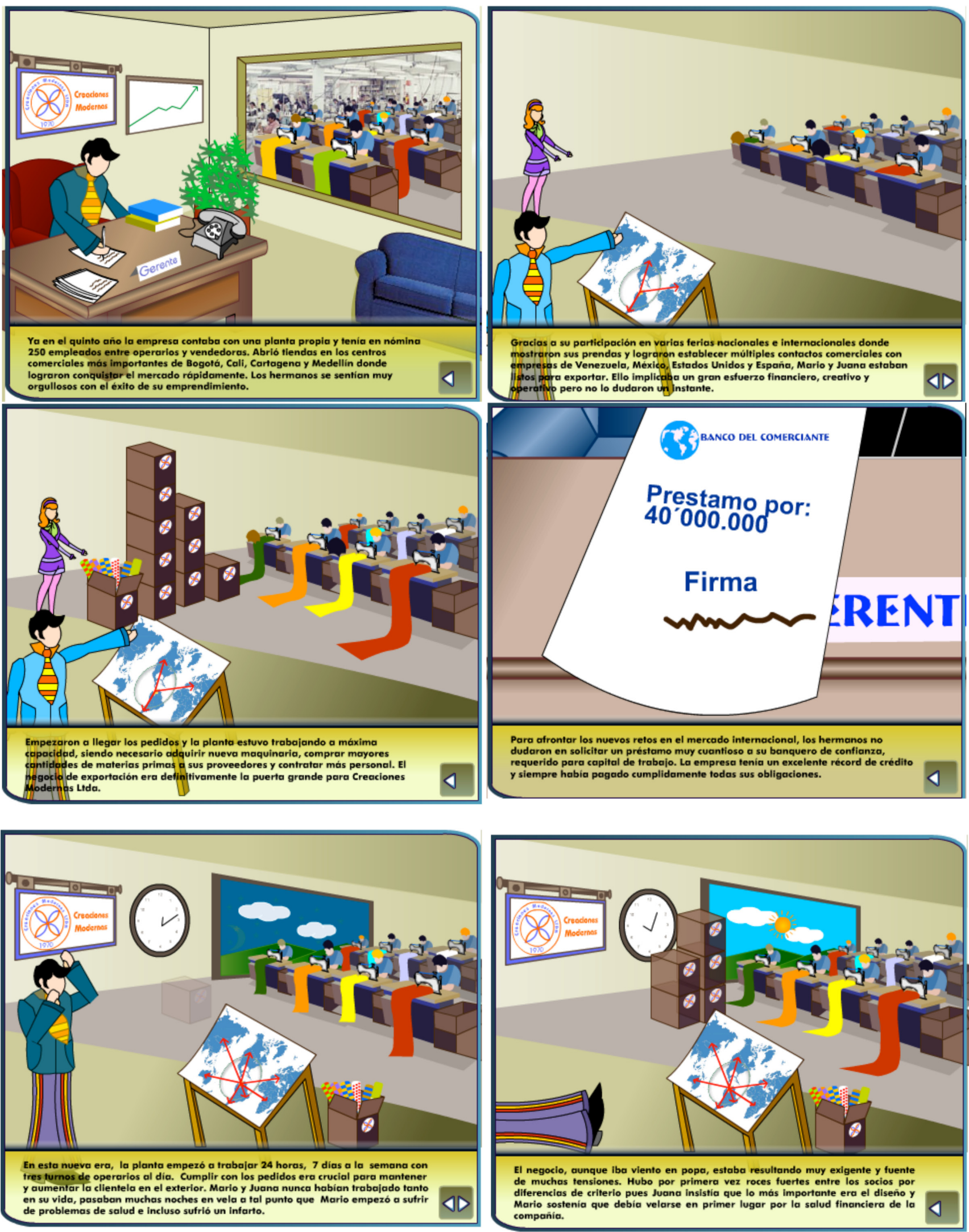

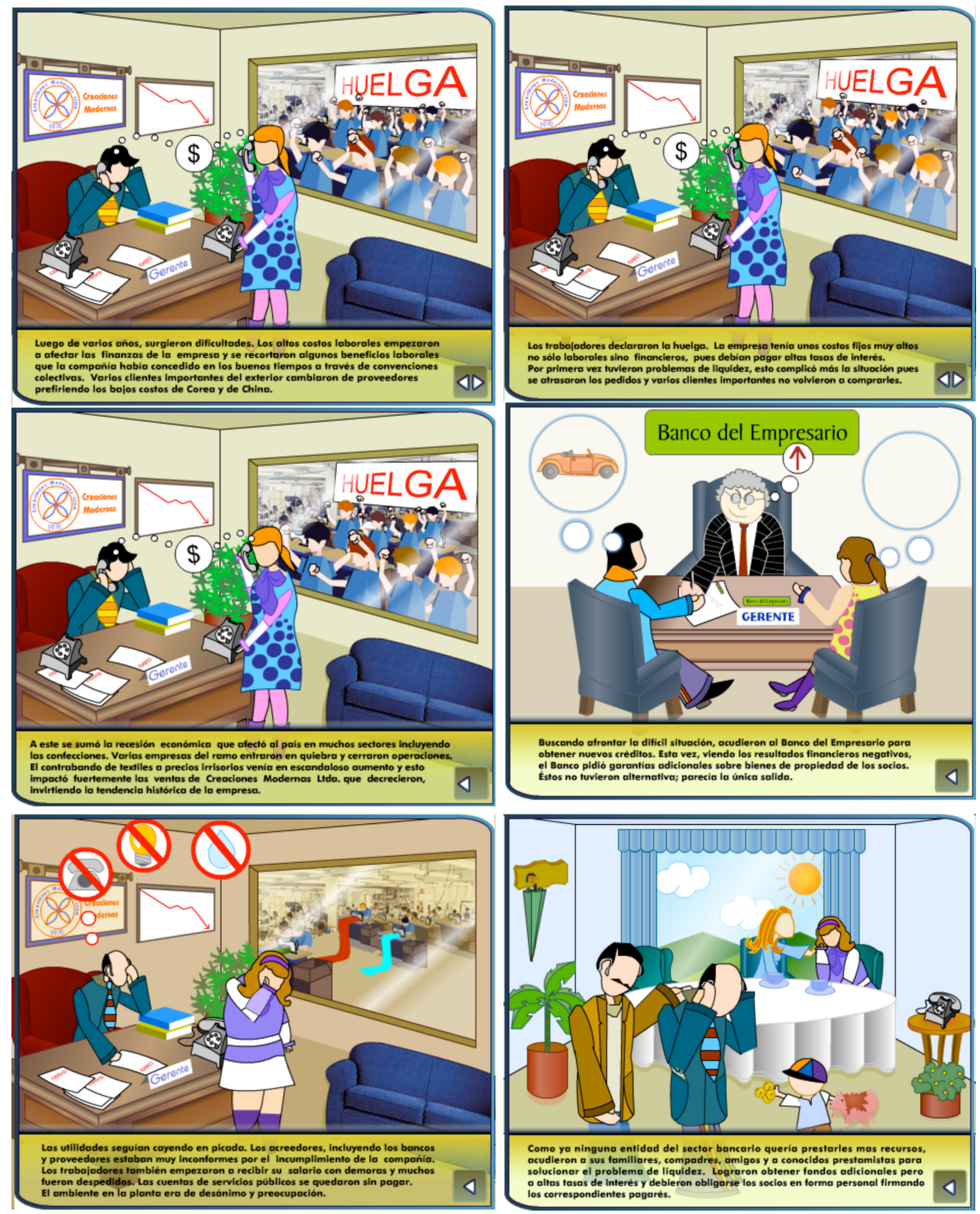

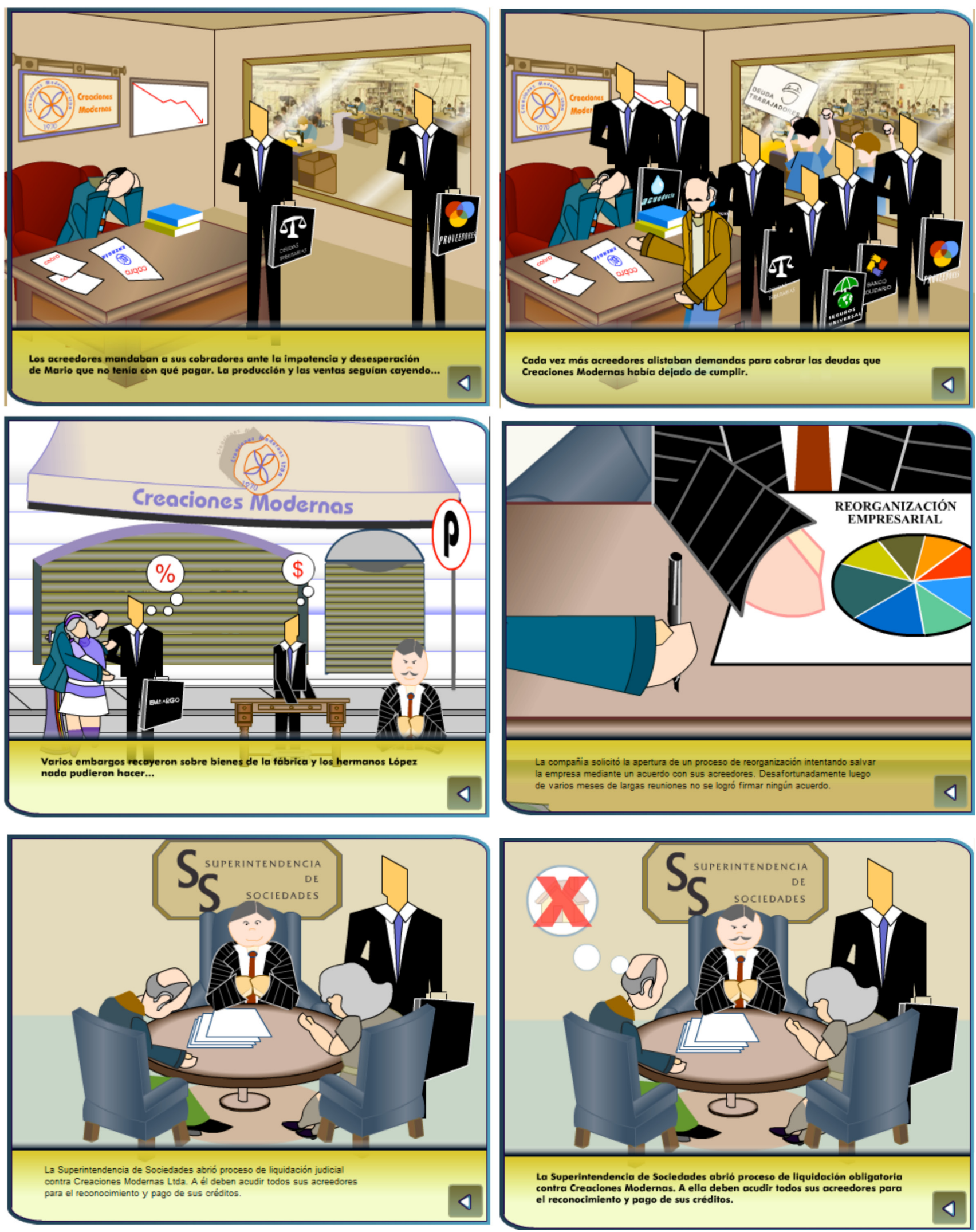
Luego de conocer estas escenas y de leer el material de referencia (principalmente normas jurídicas y doctrina especializada), la profesora entrega las instrucciones específicas del caso y dedica parte importante de la sesión de clase a explicar el objetivo y el alcance del ejercicio. ${ }^{24}$

La simulación consta de dos partes que se complementan entre sí. En la primera parte se forman diez grupos, asignados al azar por la profesora, cada uno de los cuales actuará como equipo de abogados que representa a uno de los diez acreedores. Estos grupos deben elaborar, en representación de su cliente, los documentos necesarios para presentar el respectivo crédito al proceso concursal de liquidación. En audiencia, cada grupo expone oralmente su trabajo y entrega los documentos elaborados. La profesora, actuando en calidad de funcionaria de la Superintendencia de Sociedades encargada del proceso, indaga por los conceptos jurídicos subyacentes e invita a los miembros de los demás grupos a hacer comentarios, aportes y observaciones. Los documentos presentados en esta primera fase son evaluados con base en la matriz de evaluación que se da a conocer a los estudiantes con suficiente anticipación ${ }^{25}$.

Con los documentos entregados en la audiencia, los estudiantes se preparan para la segunda parte del ejercicio: la graduación de créditos. Ahora, actuando como Superintendencia de Sociedades, deben estudiar el expediente que

24 Ver anexo 9: cifras e instrucciones de la simulación caso Lácteos $L a$ Vaquita Ltda.

Ver anexo 10: matriz de evaluación de la presentación de créditos. se ha conformado con los diez créditos presentados y, en una fecha posterior que se anuncia con antelación, proferir un auto de graduación en el que deben aplicar correctamente la prelación legal. La segunda parte del ejercicio se evalúa de conformidad con los criterios fijados en la matriz correspondiente ${ }^{26}$.

Una vez entregados los documentos de la segunda parte, la profesora cierra la simulación con algunas conclusiones y la resolución de inquietudes sobre el ejercicio realizado.

\section{Actividad transversal: uso del hipertexto jurídico}

Durante varios años he venido desarrollando una herramienta de apoyo para el curso Obligaciones II. El hipertexto podría definirse como una base de datos virtual que reúne los contenidos de los cuatro módulos de la materia ${ }^{27}$ y que pueden emplearse en el aula o por fuera de ella.

El hipertexto se aloja en sicua + y se accede a él a través de mapas conceptuales que muestran las subdivisiones de los distintos temas a tratar. Cada concepto se desarrolla en una celda en la que aparece una definición, los correspondientes requisitos y efectos jurídicos. A renglón seguido se formulan preguntas conceptuales y problemas que permiten aplicar la institución estudiada y reflexionar sobre ella. Finalmente,

26 Ver anexo 11: matriz de evaluación de la graduación de créditos.

27 (i) hecho ilícito como fuente de las obligaciones, (ii) efectos de las obligaciones, (iii) transmisión de las obligaciones, (iv) extinción de las obligaciones. 
aparece un listado con enlaces a fuentes normativas y jurisprudenciales y una bibliografía sugerida para estudio.

En algunas sesiones de clase utilizo el hipertexto, ya sea para introducir un concepto o al final de la unidad temática para el cierre y las conclusiones correspondientes. En dichas sesiones, que deben estar precedidas por la lectura de los materiales asignados, dedicamos una parte de la clase a desarrollar las preguntas y problemas en pequeños grupos, y luego en una plenaria ponemos todos los aportes de los estudiantes en común, resolvemos dudas, cambiamos algún supuesto y verifico que las nociones involucradas se hayan comprendido a cabalidad. En otras ocasiones, los estudiantes deben resolver dichas preguntas y problemas por fuera de clase para la preparación de otras actividades, por ejemplo, exámenes, comprobaciones o PBL.

Esta herramienta, en la cual se aprovecha la tecnología para afianzar los contenidos de la asignatura, apoya todos los objetivos pedagógicos planteados para el curso y por ello tiene un uso transversal, contribuyendo al desarrollo de las siguientes competencias:

- identificar la estructura y el régimen de las obligaciones;

- comprender los conceptos fundamentales, las instituciones, principios y reglas básicas del derecho de las obligaciones, al punto de poder relacionarlos entre sí y aplicarlos a situaciones fácticas;
- conocer el régimen colombiano vigente de las obligaciones a través del análisis de las normas, la doctrina y la jurisprudencia relevantes;

- integrar elementos de teoría y práctica en el estudio de las obligaciones, así como los aspectos sustantivos y procedimentales involucrados;

- desarrollar destrezas/habilidades básicas para resolver problemas en el campo de las obligaciones;

- conocer con suficiencia el vocabulario jurídico propio del derecho de las obligaciones, de manera que se utilice adecuada y rigurosamente.

A continuación muestro, como ejemplo, el hipertexto desarrollado para los módulos finales del curso (transmisión y extinción de las obligaciones). 


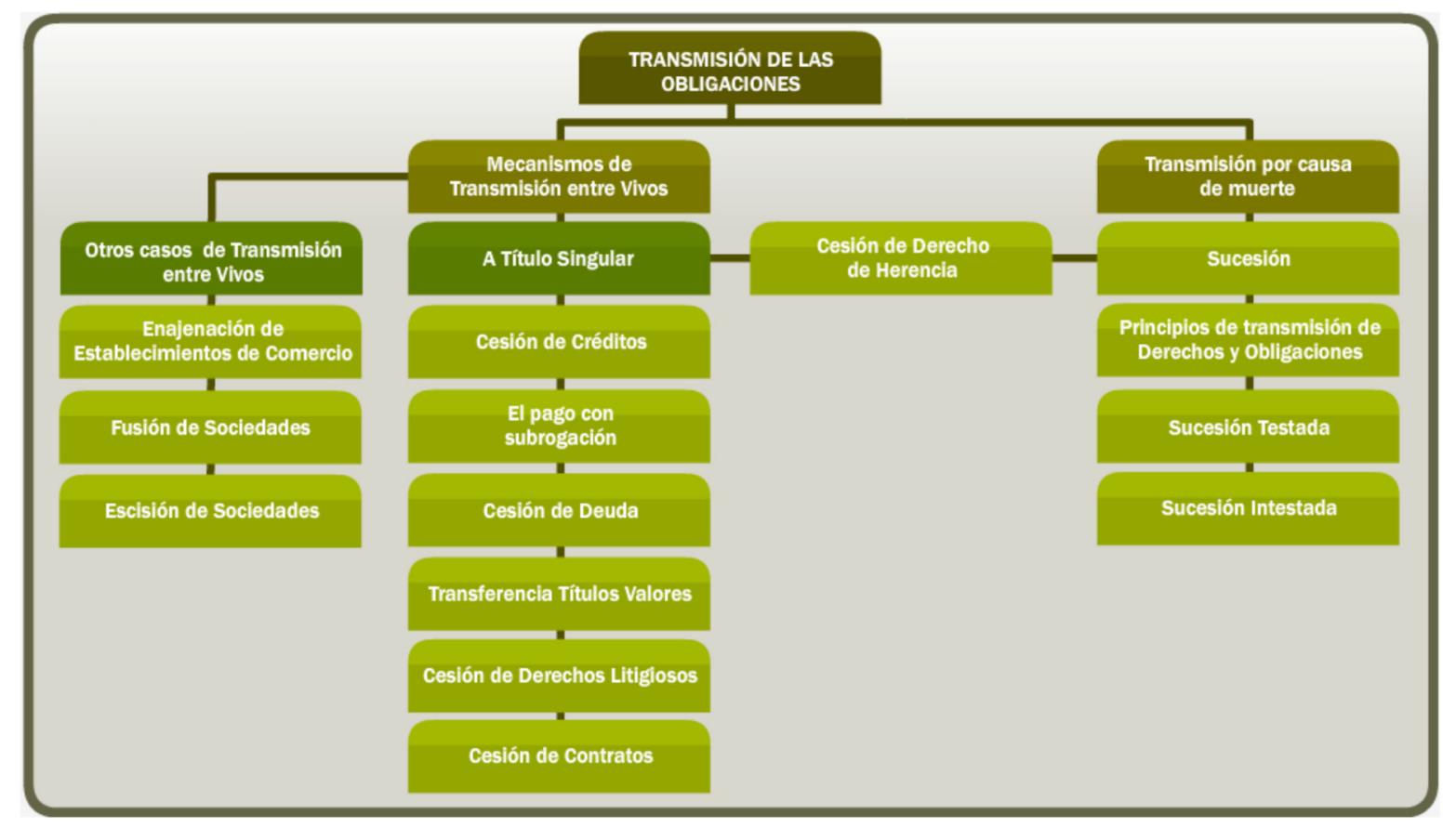

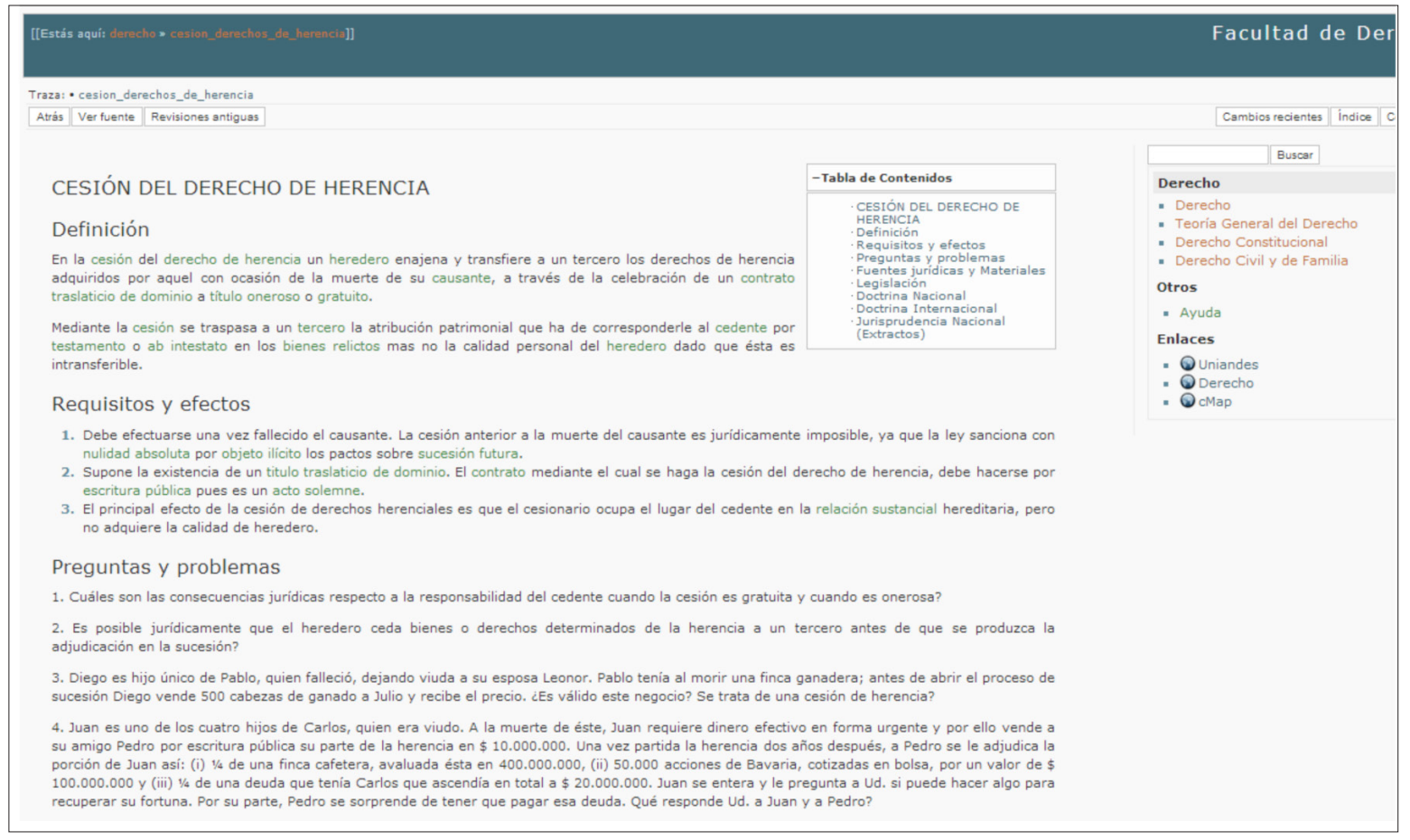


Fuentes jurídicas y Materiales

Legislación

- Código Civil

- Articulo 665

- Articulo 1155

- Articula 1857

- Articulo 1967

Doctrina Nacional

- CASTRO DE Cifuentes, MARCElA. "Transmisión de las obligaciones mortis causa". En: Derecho de las Obligaciones. Tomo II. Vol. 2 Ediciones

Uniandes- Temis Bogota, 2010 Cap. XVIII

LAFONT PIANETTA Pedro, Derecho de sucesiones, Bogotá, Ediciones Libreria del profesional, 1993.

- SUÁREZ FRANCO, Roberto, Derecho de sucesiones, Bogotá, Editorial Temis, 2003.

- AGUADO MONTANO, Eustorgio Mariano, Derecho de sucesiones, Bogotá, Editorial Leyer 2000.

Doctrina Internaciona

- claro solar, luís, Explicaciones de derecho civil chileno y comparado, Tomo XiUl Santiago, Editorial Nacimiento, 1945.

- MAZEAUD, Henri, Lecciones de derecho civil, parte 2, volumen III, Buenos Aires, Ediciones Jurídicas Europa América, 1962.

Jurisprudencia Nacional (Extractos)

- Q Corte Suprema de Justicia, Sala de Casación Civil, Sentencia Agosto 13 de 1940, M.P.: Daniel Anzola.|Corte Suprema de Justicia, Sala de Casación Civil, Sentencia Agosto 13 de 1940, M.P. Daniel Anzola

- Q Corte Suprema de Justicia, Sala de Casación Civil, Sentencia Marzo 11 de 1942, M.P.: Hernán Salamanca.|Corte Suprema de Justicia, Sala de Casación Civil, Sentencia Marzo 11 de 1942, M.P. Hernán Salamanca

- Q Corte Suprema de Justicia, Sala de Casación Civil, Sentencia Marzo 22 de 1944, M.P.: Liborio Escallón.|Corte Suprema de Justicia, Sala de Cación Civil, Sentencia Marzo 22 de 1944, M.P. Liborio Escallón

- Q Corte Suprema de Justicia, Sala de Casación Civil, Sentencia Septiembre 30 de 1955, M.P.: José Hernández Arbeláez.|Corte Suprema de Justicia, Sala de Casación Civil, Sentencia Septiembre 30 de 1955, M.P. José Hernández Arbeláez

- Q Corte Suprema de Justicia, Sala De Casación Civil, Sentencia Junio 23 de 1958, M.P.: Arturo C. Posada.|Corte Suprema de Justicia, Sala De Casación Civil, Sentencia Junio 23 de 1958, M.P. Arturo C. Posada

- Z Corte Suprema de Justicia, Sala de Casación Civil, Sentencia Febrero 22 de 1967, M.P. Enrique López De La Pava

- ¿ Corte Suprema de Justicia, Sala de Casación Civil, Sentencia Enero 30 de 1970, M.P.: Guillermo Ospina Fernández.lCorte Suprema de Justicia,

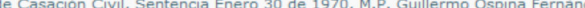

- Q Corte Suprema de Justicia, Sala De Casación Civil, Sentencia Septiembre 9 de 1970, Magistrado Ponente Ernesto Cediel Ánge

- Q Corte Suprema de Justicia, Sala De Casación Civil, Sentencia Septiembre 29 de 1984, M.P. Horacio Montoya Gil

- ๑ Corte Suprema de Justicia, Sala De Casación Civil, Sentencia S 049 De Agosto 27 se 1997, Magistrado Ponente Nicolás Bechara Simancas

- Z Corte Suprema de Justicia, Sala de Casación Civil, Sentencia del 5 de noviembre de 2003, Magistrado Ponente Cesar Julio Valencia Copete

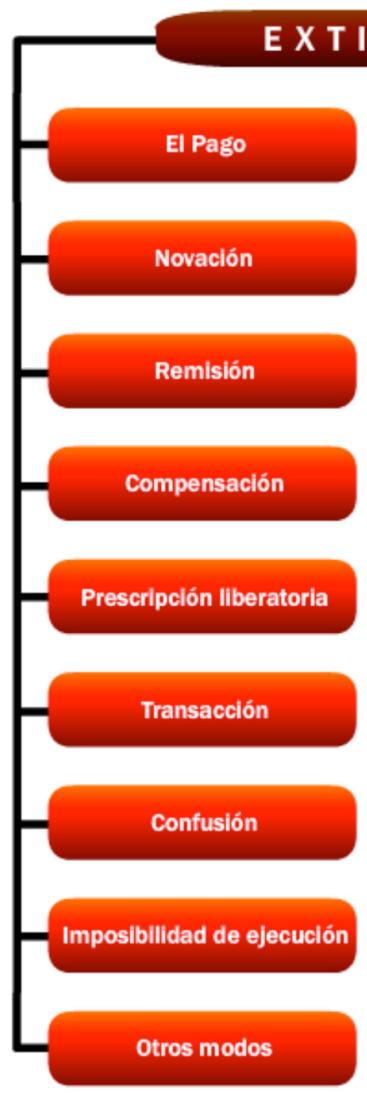



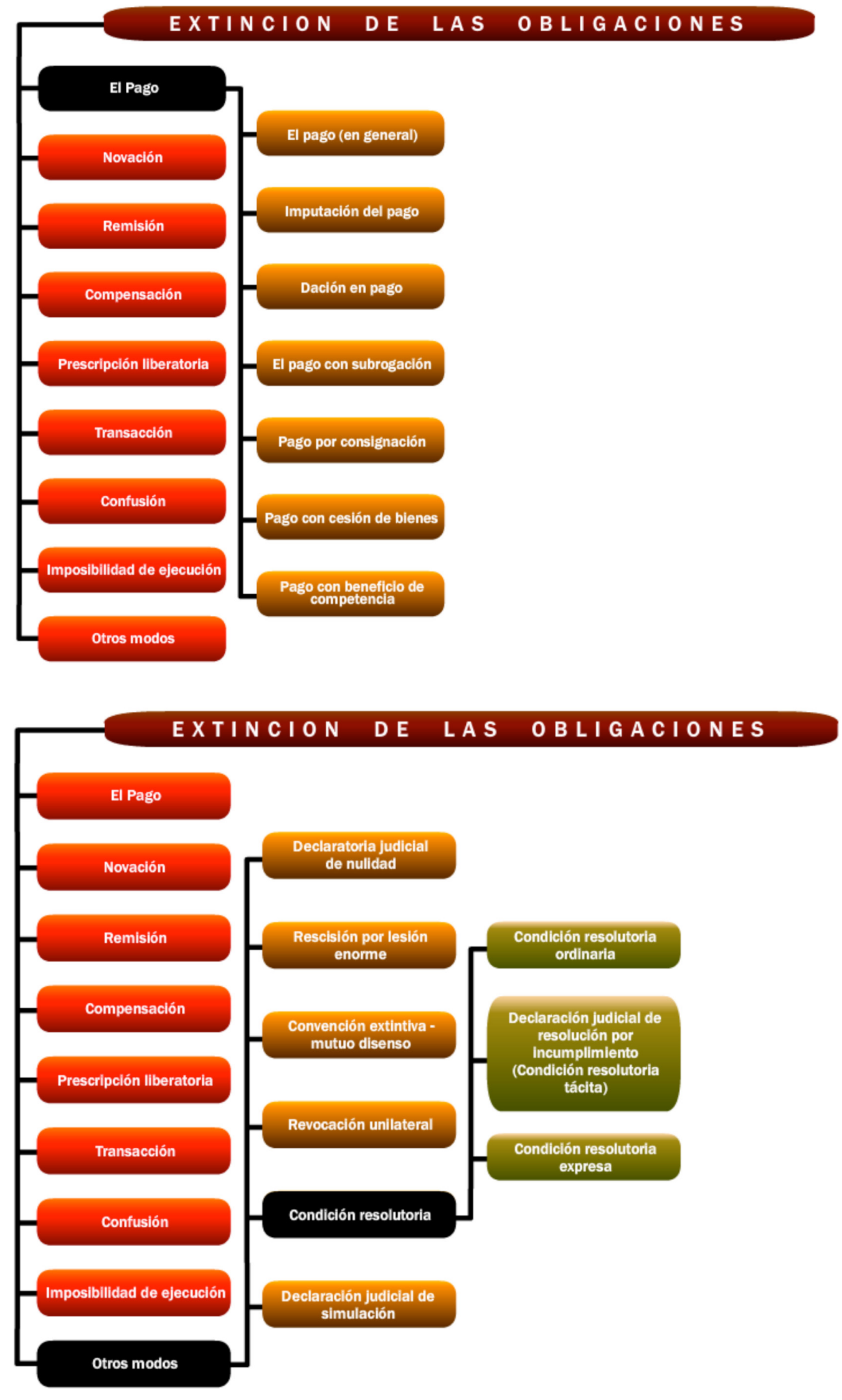


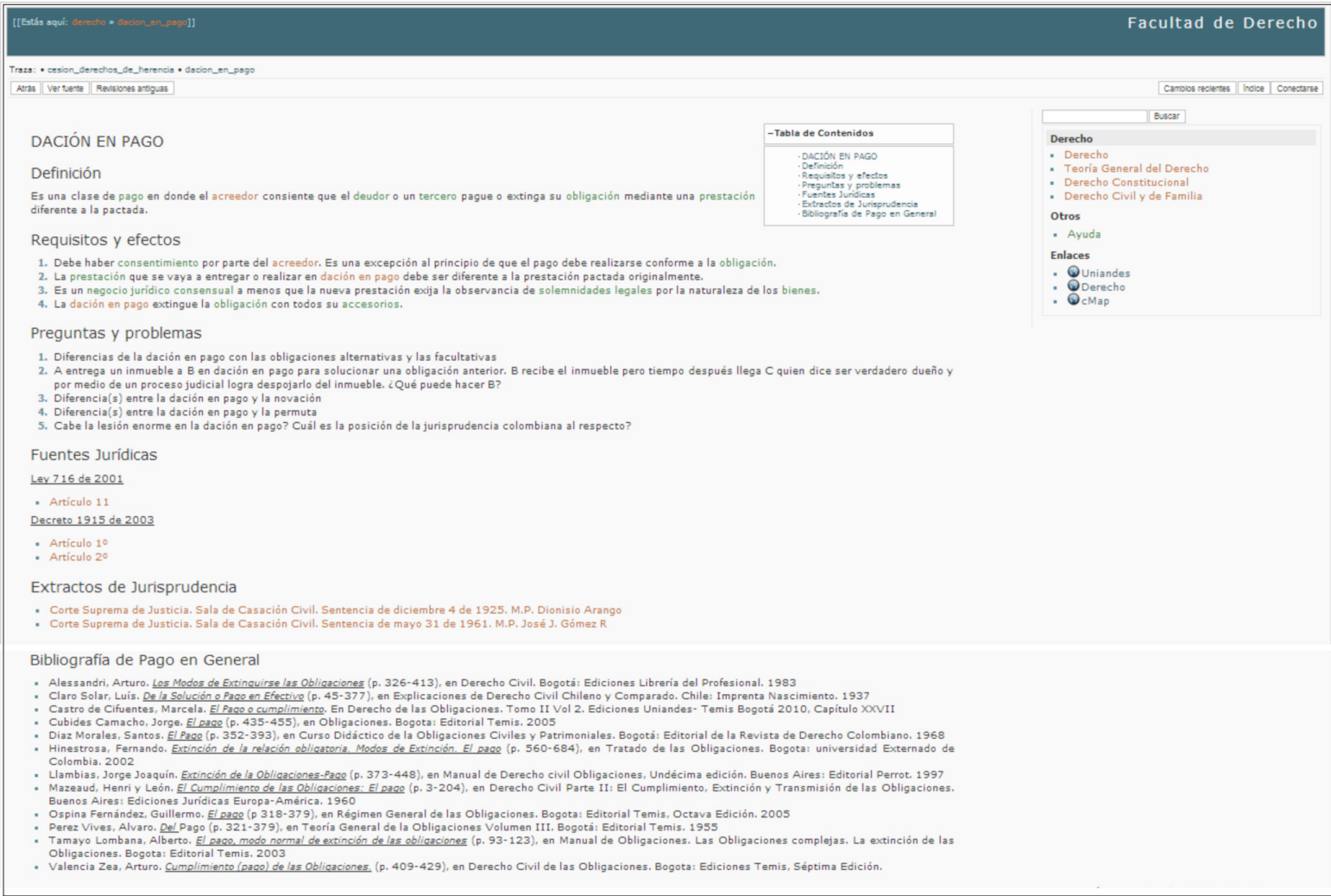

El hipertexto, como herramienta transversal, puede utilizarse en cualquiera de los módulos pero no me apoyo en él en todas las sesiones porque resultaría monótono y se perdería la oportunidad de acudir a actividades variadas, que considero muy provechosas. Ha resultado muy útil para los estudiantes al prepararse para sus clases, exámenes, y sobre todo para las actividades de evaluación auténtica que he explicado atrás. No sustituye la discusión en grupo ni es suficiente como material para comprender todos los conceptos que se involucran en el curso.

\section{ALGUNOS RESULTADOS EN EL PROCESO DE APRENDIZAJE}

Con la participación en las actividades diseñadas en el curso Obligaciones II los estudian- tes desarrollan importantes competencias que muestran el cumplimiento de los objetivos pedagógicos propuestos. En particular, los siguientes, formulados en el programa y reseñados anteriormente:

- Comprender los conceptos fundamentales, las instituciones, principios y reglas básicas del derecho de las obligaciones al punto de poder relacionarlos entre sí y aplicarlos a situaciones • - fácticas; Integrar elementos de teoría y práctica en el estudio de las obligaciones, así como los aspectos sustantivos y procedimentales involucrados;

- Desarrollar destrezas/habilidades básicas para resolver problemas en el campo de las obligaciones; 
- Conocer con suficiencia el vocabulario jurídico propio del derecho de las obligaciones, de manera que se utilice adecuada y rigurosamente en presentaciones orales y escritas.

En el juicio de responsabilidad civil con juego de roles presento, a título ilustrativo, el laudo arbitral (decisión final) proferido por el grupo de árbitros, mediante el cual resuelven la controversia surgida entre las partes. En este documento los estudiantes deben demostrar conocimiento suficiente del tema, valorar los argumentos de las partes, presentar su propia línea argumentativa y tomar una decisión fundada en las fuentes aplicables. ${ }^{28}$

En el ejercicio de simulación del proceso concursal de liquidación judicial los estudiantes presentan un auto de reconocimiento y graduación de créditos, en el que aprenden a aplicar la prelación legal de los distintos acreedores involucrados y establecen las sumas a pagar en una situación de insolvencia. ${ }^{29}$

\section{REFLEXIÓN Y CONCLUSIONES}

El trabajo que he realizado en el curso Obligaciones II durante los últimos años me ha permitido tomar conciencia de la necesidad de que mi labor pedagógica evolucione y mejore en forma constante. No solo es indispensable para los profesores y profesoras actualizar los contenidos de sus programas, sino tener claros los ob-

Ver anexos 2 y 12. Caso "Un viaje sin regreso".

29 Ver anexo 13. jetivos de sus cursos para así diseñar diversas actividades que, con apoyo en metodologías activas, promuevan el aprendizaje autónomo y colaborativo. Considero, además, que aunque no se enuncia explícitamente la investigación como objetivo del curso, de hecho, los estudiantes desarrollan esta habilidad en el nivel deseable para el pregrado de la Facultad, es decir, ellos de manera autónoma "aprenden a aprender" con la guía del profesor y de un programa animado por ese propósito.

Las innovaciones que he descrito se centran en el diseño de distintas actividades que buscan guardar coherencia con los objetivos propuestos en la asignatura específica y en la Facultad como un todo. La tecnología ha sido un componente importante del trabajo, en la medida que ha apoyado el proceso de enseñanza-aprendizaje.

Como lo resalté al comienzo, este no ha sido un esfuerzo individual; he contado con el constante apoyo de la Universidad, de la Facultad de Derecho, del Programa Sócrates, del CIFE, del Laboratorio LIDIE, de colegas profesores de obligaciones, de varios monitores, así como de estudiantes y personal de apoyo en el área de sistemas.

Además, debo ser honesta al expresar que las actividades descritas no están exentas de problemas, de los cuales enuncio solo algunos: 1 ) falta de conocimiento previo de los estudiantes de materias que, como derecho procesal, darían mayores herramientas para el ejercicio del tribunal arbitral; 2) falta de disponibilidad de salas de audiencias para desarrollar adecuadamente 
el juego de roles y la simulación; 3) problemas típicos del trabajo en grupo, que si bien obedecen a un criterio de evaluación auténtica porque los abogados solemos trabajar en equipo, puede diluirse la responsabilidad y el grado de aprendizaje de sus miembros.

Quedan por delante varios desafíos a los que tendré que enfrentarme en un futuro cercano, como mis propias limitaciones de tiempo para dedicarme con mayor amplitud a diseñar nuevas alternativas que sirvan para evaluar si los objetivos propuestos van por buen camino o si estos deben reformularse y requieren, en consecuencia, nuevas estrategias pedagógicas. Entre ellas, hacer explícito en el programa el objetivo de investigar en el sentido descrito de "aprender a aprender", que constituye a mi juicio una competencia de primer orden en la formación de los futuros juristas.

Para los profesores, la investigación en el campo de las obligaciones -en el sentido de contribuir al análisis profundo y al avance de la disciplina- es un imperativo si queremos estar al día en el estado del arte y aprovechar este conocimiento en beneficio de una enseñanza con excelencia. Así mismo, es inaplazable el debate sobre la modernización de las obligaciones, el cual debe promover una sana reflexión entre profesores y estudiantes para despejar el futuro de esta importante disciplina jurídica. Todo esto enriquecerá una asignatura que, por tradicional, no deja de ser de la esencia en la formación de los futuros abogados.
Por último, reitero mi agradecimiento a la Facultad de Derecho por el reconocimiento que hace a los profesores, por sus esfuerzos encaminados a innovar en docencia. En particular, por el Premio a la Innovación Docente que me otorgó en 2012, año de la primera edición del concurso, por mi labor pedagógica en Obligaciones II.

\section{Bibliografía}

BAIN, Ken. Lo que hacen los mejores profesores de Universidad. Óscar Barberá (tr.). Universidad de Valencia, 2007.

CALDERÓN VILLEGAS, Juan Jacobo. La constitucionalización del derecho privado en Colombia: la verdadera historia del impacto constitucional en Colombia. Bogotá: Universidad de los Andes, Universidad del Rosario, Temis, 2011.

CIFE. Competencias profesionales de los programas de Derecho. Bogotá: Universidad de los Andes, 2012.

CIFE. Sistema de evaluación de la efectividad de los programas educativos de la Universidad de los Andes. Bogotá: autor, 2010.

DUPLÁ MARÍN, Teresa. La recepción del derecho romano en el movimiento de unificación del derecho privado y la Constitución europea. Disponible en: http://ruc.udc.es/dspace/ bitstream/2183/2225/1/AD-7-14.pdf

FERNÁNDEZ MARCH, Amparo. Metodologías activas para formar en competencias. Pp. 36 y 
ss. Disponible en: http://revistas.um.es/index.php/educatio/article/viewFile/152/135

OTERO CLEVES, Ana María y JIMÉNEZ ÁNGEL, Andrés. Cuarenta años innovando el derecho: una mirada a la Facultad de Derecho de la Universidad de los Andes. Bogotá: Uni- versidad de los Andes, Facultad de Derecho, 2010.

POSNER, George. Análisis del currículo. Miguel Ángel Martínez (tr.). $3^{a}$ ed. México: McGraw Hill, 2005. 


\section{ANEXO 1: PROGRAMA DE OBLIGACIONES II (RESUMIDO)}

ANEXOS

\section{OBLIGACIONES (I y II)}

TEMAS

1. Concepto y elementos de la obligación*

2. Clasificación de las obligaciones*

3. Fuentes de las obligaciones

Clasificación de las fuentes

El acto o negocio jurídico*

El hecho ilícito**

El enriquecimiento sin causa*

La ley*

4. Efectos de las obligaciones**

5. Transmisión de las obligaciones**

6. Extinción de las obligaciones**

* Temas de Obligaciones I

** Temas de Obligaciones II

(Ver Programa General de Obligaciones I y II)

\section{OBLIGACIONES II}

\section{Presentación}

El curso Obligaciones II es el módulo final dentro del programa de Obligaciones, en el Ciclo de formación jurídica básica de la Facultad de Derecho. Se pretende que este módulo se integre a la unidad temática precedente, con el propósito de que el estudiante tenga una visión completa y no fraccionada de las obligaciones en el derecho privado. Igualmente, busca enfatizar que las obligaciones constituyen una estructura de principios y conceptos fundamentales, aplicable a todas las ramas del derecho.

Es importante recapitular sobre los principales aspectos abordados en Obligaciones I, los cuales deben conocer suficientemente los estudiantes para que el curso logre la continuidad deseable:

\section{Concepto y elementos de la obligación.}

2. Clasificación de las obligaciones.

3. Fuentes de las obligaciones: el acto o negocio jurídico, la ley, el enriquecimiento sin causa.

En el presente semestre, para completar la estructura general del derecho de las obligaciones se estudiarán los siguientes temas, los cuales se han dividido en cuatro partes, para efectos pedagógicos. Previamente y como punto introductorio, se hará una breve recapitulación de los temas fundamentales del derecho de las obligaciones para lograr una visión integrada del mismo.

\section{PRIMER MÓDULO. FUENTES DE LAS OBLIGACIO- NES (continuación): EL HECHO ILÍCITO}

Se examinará el sistema general de la responsabilidad civil, en sus elementos, requisitos y 
manifestaciones (contractual, extracontractual y precontractual). Se estudiará su régimen legal haciendo especial énfasis en la jurisprudencia de la Corte Suprema de Justicia, la cual, a lo largo de los años, ha interpretado la ley civil y ha evolucionado de forma tal que ha generando un conjunto de importantes principios en esta materia.

\section{SEGUNDO MÓDULO. EFECTOS DE LAS OBLIGA-} CIONES

Este aparte se dedicará a revisar los derechos de los acreedores. Se recalcará la función de prenda general que cumple el patrimonio del deudor en favor de sus acreedores y la interacción de los elementos sustantivos y procedimentales en esta materia. Se analizarán las reglas concernientes a la ejecución forzosa como principal efecto de toda obligación y se estudiarán también otras instituciones jurídicas con que cuentan los acreedores para lograr la efectividad de sus créditos: la indemnización de perjuicios y las acciones tendientes a conservar y, en su caso, a reintegrar el patrimonio del deudor con el fin de ejercitar sobre este las acciones ejecutivas, individual o colectivamente.

\section{TERCER MÓDULO. TRANSMISIÓN DE LAS OBLI- GACIONES}

Bajo este capítulo se estudiará la transmisibilidad entre sujetos de los elementos patrimoniales -activos y pasivos- que se crean a partir de las relaciones obligatorias. Especial atención se dará a los principios y los mecanismos jurídicos a través de los cuales se transmiten dichos ele- mentos por causa de muerte y entre vivos. Asimismo, se discutirán las reglas del Código civil y del Código de Comercio relativas a la cesión de créditos, de deudas, de contratos y de universalidades, tanto de hecho como de derecho.

\section{CUARTO MÓDULO. EXTINCIÓN DE LAS OBLIGA- CIONES}

Teniendo en cuenta la transitoriedad que caracteriza a los vínculos obligatorios, el curso terminará con el estudio del régimen jurídico de cada uno de los modos mediante los cuales se extinguen las obligaciones.

\section{OBLIGACIONES (2013-I)}

\section{Objetivos}

Al finalizar los dos cursos de obligaciones el estudiante debe estar en capacidad de:

- Identificar la estructura y el régimen de las obligaciones, a saber: su concepto y clases, sus fuentes, sus efectos, su transmisión y su extinción valorando su importancia en el derecho privado (civil y comercial) y en el sistema jurídico en general.

- Comprender los conceptos fundamentales, las instituciones, principios y reglas básicas del derecho de las obligaciones al punto de poder relacionarlos entre sí y aplicarlos a situaciones fácticas.

- Conocer el régimen colombiano vigente de las obligaciones a través del análisis de las normas, la doctrina y la jurisprudencia relevantes. 
- Integrar elementos de teoría y práctica en el estudio de las obligaciones, así como los aspectos sustantivos y procedimentales involucrados.

- Desarrollar destrezas/habilidades básicas para resolver problemas en el campo de las obligaciones.

- Conocer con suficiencia el vocabulario jurídico propio del derecho de las obligaciones, de manera que se utilice adecuada y rigurosamente en presentaciones orales y escritas.

\section{Metodología}

El curso se desarrollará con una metodología predominantemente activa, en la que será primordial la participación de los alumnos para el desarrollo y discusión de los diferentes temas. Para tal efecto, es indispensable la lectura previa de los materiales pertinentes.

Junto con el método de aprendizaje basado en problemas (PBL) y discusión de casos, se realizarán ejercicios para desarrollo de habilidades. Periódicamente, en cada grupo, el profesor hará presentaciones que buscan integrar y estructurar la materia, precisar conceptos así como el vocabulario jurídico.

Para cada tema, los estudiantes deben consultar las normas pertinentes del Código civil, de Comercio y de Procedimiento civil, al igual que las lecturas obligatorias asignadas, sin perjuicio de la investigación adicional que se requiera para una mejor comprensión y profundización de los temas y para la resolución de problemas, casos y ejercicios (ver bibliografía del curso).

Aprendizaje basado en problemas: referirse a la metodología de resolución de problemas (Problem Based Learning -PBL de la Facultad de Derecho).

- En el primer módulo del curso se desarrollará la simulación de un juicio arbitral en donde se debatirá la responsabilidad civil (contractual, extracontractual o precontractual) de la parte demandada. Para tal efecto, la clase se dividirá en dos secciones. Posteriormente, cada sección se dividirá en tres grupos: (i) parte demandante, (ii) parte demandada y (iii) árbitros. Los dos primeros grupos deberán presentar esquemáticamente memoriales de demanda y contestación a la demanda y sus correspondientes alegatos orales, mientras que el tercero estará a cargo de fijar el contenido del litigio (acta de misión) y proferir el laudo arbitral que ponga fin a la controversia. La actividad se desarrollará en varias sesiones, que se cumplirán en las fechas señaladas en el programa conforme a las instrucciones entregadas a los estudiantes en el momento oportuno.

- En el segundo módulo se realizará un ejercicio de liquidación judicial de una sociedad, mediante juego de roles; el curso se dividirá en dos secciones. La actividad se desarrollará en dos etapas: en la primera, la totalidad de la clase será dividida en grupos, los cuales representarán a los acreedores de la persona jurídica en estado de insolvencia y 
deberán presentar las peticiones ante el liquidador de la sociedad para que se les reconozcan y califiquen los respectivos créditos. Posteriormente, los mismos grupos fungirán de juez del concurso para reconocer y calificar dichas acreencias, de conformidad con la prelación de créditos.

Casos: hipótesis fácticas para discutir y analizar la aplicación de instituciones y normas jurídicas.

Análisis de jurisprudencia. Estudio, análisis y discusión de sentencias de la Sala de Casación Civil de la Corte Suprema de Justicia sobre temas del curso, para lo cual los estudiantes deben elaborar una ficha para cada decisión empleando los siguientes parámetros: a) Título: identificación completa de la providencia; b) Hechos relevantes; c) Problema(s) jurídico(s) planteado(s); d) Motivaciones de la Corte (incluye fuentes de derecho) y e) Regla jurídica aplicable (ver en SICUA+ Formato análisis de jurisprudencia). Cualquier miembro del grupo puede ser requerido para exponer el análisis de la sentencia en discusión. Se darán bonos individuales en el taller de jurisprudencia a quienes realicen investigación de jurisprudencia de los temas señalados por la profesora y el monitor, que no esté contenida en el material bibliográfico del curso o en el hipertexto jurídico.
Ejercicios. Actividades prácticas que permiten al estudiante desempeñar un rol y desarrollar habilidades específicas en el campo del derecho.

Presentaciones del profesor/discusiones. Buscan integrar y estructurar los temas del curso.

SICUA+. El curso contará con el apoyo pedagógico del Sistema Interactivo de Cursos de la Universidad de los Andes (SICUA+), el cual debe ser consultado en forma permanente.

Hipertexto. El hipertexto es una herramienta de apoyo permanente del curso, la cual debe consultarse en SICUA+.

\section{Evaluación}

El rendimiento académico del estudiante se evaluará con base en:

- Actividad del alumno en el grupo, que consistirá en: i) preparación previa para cada sesión, ii) asistencia a las sesiones con participación activa y constructiva, iii) trabajo en casos, controles de lectura, ejercicios, PBL y análisis de jurisprudencia.

- Su desempeño individual en las pruebas y evaluaciones del curso. 
Los porcentajes asignados son los siguientes:

\begin{tabular}{|l|c|c|c|}
\hline Primera parte: responsabilidad civil & & & \\
\hline Juicio de responsabilidad civil & & & \\
\hline Esquema de planteamiento del caso & $5 \%$ & & \\
\hline Alegatos de conclusión /laudo arbitral & $10 \%$ & & \\
\hline Taller de jurisprudencia & $10 \%$ & & \\
\hline Quiz & $10 \%$ & & \\
\hline Total primera parte & & $35 \%$ & \\
\hline Segunda parte: efectos de las obligaciones & & & \\
\hline $\begin{array}{l}\text { Ejercicio de liquidación judicial } \\
\text { Memorial presentación de créditos } \\
\text { Auto de graduación y calificación de créditos } \\
\text { Subtotal }\end{array}$ & $10 \%$ & & \\
\hline $\begin{array}{l}\text { Transmisión de las obligaciones } \\
\text { Parcial (incluye efectos de las obligaciones) }\end{array}$ & $10 \%$ & $20 \%$ & $15 \%$ \\
\hline $\begin{array}{l}\text { Extinción de las obligaciones } \\
\text { PBL }\end{array}$ & & $10 \%$ & \\
\hline Examen final & & $20 \%$ & \\
\hline TOTAL & & & $\underline{100 \%}$ \\
\hline
\end{tabular}

\section{CONTENIDO}

Introducción. Repaso estructura general de las obligaciones. Concepto, clases, fuentes, efectos, transmisión y extinción.

Primer módulo. Fuentes de las obligaciones. El hecho ilícito como fuente de obligaciones (continuación Tema 3 del Programa General de Obligaciones)

3.3 El hecho ilícito

3.3.1. Noción previa: la responsabilidad jurídica.

3.3.2. Sistema de responsabilidad civil

3.3.2.1. La responsabilidad civil contractual

3.3.2.2. La responsabilidad civil extracontractual
3.3.2.3. La responsabilidad precontractual (culpa in contrahendo)

3.3.3. Elementos de la responsabilidad civil

3.3.3.1. El perjuicio o daño

3.3.3.1.1 Concepto

3.3.3.1.2 Requisitos del daño indemnizable

3.3.3.1.3. Clases de perjuicios

3.3.3.1.3.1 Directos e indirectos

3.3.3.1.3.2. Ciertos y eventuales

3.3.3.1.3.3. Actuales y futuros

3.3.3.1.3.4. Materiales (daño emergente, lucro cesante) y extrapatrimoniales (daño moral, 
daño fisiológico, daño en la vida de relación)

3.3.3.1.3.6. Previsibles e imprevisibles

\subsection{Compensatorios y moratorios}

3.3.3.1.4. Evaluación y prueba del perjuicio: judicial, legal (ej.: intereses) y convencional (cláusula penal - naturaleza y funciones)

3.3.3.1.5. Autonomía de la voluntad para regular la responsabilidad: cláusulas para limitar, agravar o exonerar la responsabilidad

3.3.3.2. Elemento subjetivo: la culpa y el dolo

3.3.3.2.1. Responsabilidad subjetiva. Hecho culposo: enfoques sobre la culpa en la responsabilidad civil

3.3.3.2.1.1. Responsabilidad contractual: incumplimiento injustificado del contrato

3.3.3.2.1.1.1. Teoría de prestación de culpas

3.3.3.2.1.1.2 Presunción de culpa: obligaciones de resultado

3.3.3.2.1.2. Responsabilidad extracontractual: violación del deber general de diligencia y prudencia. Casos particulares:

3.3.3.2.1.2.1. Responsabilidad directa: por el hecho propio

Responsabilidad indirecta: por el hecho ajeno

3.3.3.2.1.2.3. La responsabilidad civil de las personas jurídicas
Daños causados por cosas

Actividades peligrosas. Presunción de culpa

3.3.3.2.2. Responsabilidad objetiva

3.3.3.3 El nexo causal

3.3.3.3.1. Teoría de la causa eficiente

3.3.3.3.2. Equivalencia de condiciones

3.3.3.3.3. Concurrencia de causas y de culpas

3.3.3.3.4. El daño indirecto

3.3.3.4. La causa extraña como eximente de responsabilidad

3.3.3.4.1. Fuerza mayor y caso fortuito. Requisitos constitutivos. La teoría del riesgo

3.3.3.4.2. Hecho de un tercero

3.3.3.4.3. Hecho de la víctima

3.3.4. El seguro de responsabilidad civil

3.3.5. Responsabilidad civil y penal

Sequndo módulo. Efectos de las obligaciones: derechos de los acreedores (tema 4 del Programa General de Obligaciones)

4.1. Patrimonio como prenda general y derechos de los acreedores

4.2. Derechos principales de los acreedores 
4.2.1. La ejecución forzosa: aspectos sustanciales y procesales

4.2.1.1. Formas y casos de ejecución: obligaciones de dar, hacer y no hacer

4.2.1.2. Ejecución individual:

4.2.1.2.1. Ejecución singular y con garantía real

4.2.1.2.2. Título ejecutivo y medidas cautelares

4.2.1.3. Ejecución colectiva: liquidación del patrimonio

\subsection{Los procesos concursales}

\subsection{Liquidación obligatoria}

4.2.1.3.1.2. El concordato y el proceso de reestructuración empresarial (nuevo régimen de insolvencia: Ley 1116 de 2006)

4.2.2. La indemnización de perjuicios

4.2.2.1. Clases: compensatoria y moratoria

4.2.2.2. Requisitos

4.2.2.2.1. Mora debitoria: constitución en mora; reconvención y excepciones

\subsection{Perjuicio}

4.3. Derechos auxiliares de los acreedores

4.3.1. Medidas conservatorias del patrimonio del deudor

\subsubsection{Generales}

4.3.1.3. Especiales. El derecho de retención

4.3.2. Medidas reconstitutivas

4.3.2.1. Acción Pauliana

4.3.2.2. Acción de simulación

4.3.2.3. Revocatoria de los actos del deudor concursado

4.3.2.4. Otros: subrogación de acreedores, acción oblicua

Tercer módulo. Transmisión de las obligaciones (tema 5 del Programa General de las Obligaciones)

5.1. A título universal: sucesión mortis causa

5.1.1. Principios de transmisión de derechos y obligaciones por causa de muerte

5.1.2. Sucesión testada e intestada

5.1.3. La cesión del derecho de herencia

5.2. A título singular: transmisión inter vivos

5.2.1. Cesión singular de créditos

5.2.2. Transferencia de títulos valores

5.2.3. Cesión singular de deudas

5.2.4. Cesión de derechos litigiosos 
5.2.5. Cesión de posición contractual

5.2.6. Transferencia de universalidades: el establecimiento de comercio

5.2.7. Transferencias patrimoniales en bloque: fusión y escisión de sociedades

Cuarto módulo. Extinción de las obligaciones (tema 6 del Programa General de Obligaciones)

\subsection{Pago}

\subsubsection{Concepto}

6.1.2. Requisitos

6.1.3. Imputación de pagos

6.1.4. Pago con subrogación

6.1.5. Pago por consignación

6.1.6. Pago con beneficio de competencia

6.1.7. Dación en pago

6.1.8. Pago con cesión de bienes

6.1.9. Pago con títulos valores

6.1.10. Cláusulas de valor (valutarias) - unidades de valor y moneda extranjera

6.2. Novación

6.2.1. Concepto

6.2.2. Clases
6.2.3. Requisitos

6.3. Compensación

6.3.1. Concepto

6.3.2. Clases

6.3.3. Requisitos

6.4. Confusión

6.4.1. Concepto

6.4.2. Requisitos

6.5. Remisión

6.5.1. Concepto

6.5.2. Clases

6.5.3. Requisitos

6.6. Transacción

6.6.1. Concepto

6.6.2. Clases

6.6.3. Requisitos - la materia transigible; formalidades

\subsection{Prescripción liberatoria}

6.7.1. Concepto - distinción con prescripción adquisitiva

6.7.2. Requisitos 
6.7.3. De acciones ordinarias y ejecutivas

6.7.4. Prescripciones de corto tiempo

6.7.5. Renunciabilidad

6.7.6. Prescripción y caducidad

6.8. La imposibilidad de ejecución

6.8.1. Fuerza mayor y caso fortuito - imposibilidad en obligaciones de dar, hacer y no hacer

6.8.2. Pérdida de la cosa debida
6.8.3. Muerte del deudor o del acreedor

6.9. Modos indirectos

6.9.1. Revocación unilateral

6.9.2. Convención extintiva: mutuo disenso expreso y tácito

6.9.3. Condición resolutoria

6.9.4. Declaración judicial de nulidad

6.9.5. Declaración de simulación 
CALENDARIO 2013-I

Iniciación clases: 21 de enero: terminación de clases: 10 de mayo

\begin{tabular}{|c|c|c|c|}
\hline Sesión & Tema & Lectura $^{30}$ & Normas/ actividad \\
\hline $\begin{array}{l}1 / \text { ( } 21 \text { de } \\
\text { enero) }\end{array}$ & Presentación - Introducción. & & \\
\hline $\begin{array}{l}2 / \text { ( } 23 \text { de } \\
\text { enero) }\end{array}$ & $\begin{array}{l}\text { SISTEMA DE RESPONSABILIDAD CIVIL } \\
\text { Responsabilidad contractual y extracontrac- } \\
\text { tual; precontractual. }\end{array}$ & $\begin{array}{l}\text { 2A - CASTRO, Marcela: el hecho } \\
\text { ílícito - Nociones fundamentales } \\
\text { - El sistema de responsabilidad } \\
\text { civil. } \\
\text { 2B- Hipertexto. }\end{array}$ & Discusión \\
\hline $\begin{array}{l}3 /(28 \mathrm{de} \\
\text { enero) }\end{array}$ & $\begin{array}{l}\text { El perjuicio o daño. } \\
\text { Concepto y requisitos del daño indemnizable. } \\
\text { Perjuicios directos/indirectos. } \\
\text { Perjuicios ciertos/eventuales. } \\
\text { Perjuicios actuales/futuros. } \\
\text { Perjuicios compensatorios/moratorios. }\end{array}$ & $\begin{array}{l}\text { 3A- GONZÁLEZ, Álvaro. El daño o } \\
\text { perjuicio. Pp. 43-118. } \\
\text { 3B- Hipertexto. }\end{array}$ & $\begin{array}{l}\text { Arts. } 1613-1614 \text { C. C. } \\
\text { Art. } 94 \text { Código penal. } \\
\text { Discusión. }\end{array}$ \\
\hline $\begin{array}{l}4 /(30 \text { de } \\
\text { enero ) }\end{array}$ & $\begin{array}{l}\text { Indemnización: daño emergente y lucro ce- } \\
\text { sante. } \\
\text { Perjuicios materiales/extrapatrimoniales. } \\
\text { Previsibles/imprevisibles. } \\
\text { Evaluación: judicial, legal y convencional. } \\
\text { Cláusula penal. Autonomía de la voluntad } \\
\text { para regular la responsabilidad. }\end{array}$ & $\begin{array}{l}\text { 4A- TAMAYO Javier. Tratado de } \\
\text { RC... Clasificación de los daños y } \\
\text { perjuicios. Pp. 470-523. } \\
\text { 4B- CSJ 31-07-2008. } \\
\text { 4C- CSJ 05-10-1999. } \\
\text { 4D- Hipertexto. }\end{array}$ & $\begin{array}{l}\text { Arts. } 1592-1601,1613- \\
1614 . \\
\text { Art. } 867 \text { C. Co. }\end{array}$ \\
\hline $\begin{array}{l}5 /(4 \text { de } \\
\text { febrero ) }\end{array}$ & $\begin{array}{l}\text { Elemento subjetivo: culpa o dolo. Resp. } \\
\text { subjetiva. Hecho culposo: enfoques sobre la } \\
\text { culpa en la responsabilidad civil. }\end{array}$ & $\begin{array}{l}\text { 5A- GAMBOA, Juan Ignacio. El- } \\
\text { emento subjetivo - La culpa y el } \\
\text { dolo en la RC. } \\
\text { 5B- Hipertexto. }\end{array}$ & $\begin{array}{l}\text { Art. } 2341 \text { C. C. } \\
\text { Discusión } \\
\text { Ejercicio sobre daño } \\
\text { indemnizable }\end{array}$ \\
\hline $\begin{array}{l}6 / \text { (6 de } \\
\text { febrero) }\end{array}$ & $\begin{array}{l}\text { Resp. contractual: incumplimiento injustifi- } \\
\text { cado del contrato. Teoría de prestación de } \\
\text { culpas. } \\
\text { Presunción de culpa: obligaciones de resul- } \\
\text { tado. } \\
\text { Resp. precontractual: culpa in contrahendo. }\end{array}$ & $\begin{array}{l}\text { 5A- GAMBOA, Juan Ignacio. El- } \\
\text { emento subjetivo - La culpa y el } \\
\text { dolo en la RC } \\
6 \text { A-CSJ } 22-07-2010 . \\
6 B-\text { CSJ 18-05-2005. } \\
\text { 6C- CSJ 26-11-1986. } \\
\text { 6D- CSJ 06-03-1972. } \\
6 \text { E- Hipertexto. }\end{array}$ & $\begin{array}{l}\text { Arts. } 1604,1613-1614, \\
63 \text { C. C. } \\
\text { Taller de jurispruden- } \\
\text { cia I }\end{array}$ \\
\hline
\end{tabular}

30 Salvo referencia en contrario, todas las lecturas corresponden al libro Derecho de las Obligaciones, tomo II, de la Facultad de Derecho de la Universidad de los Andes, 2010. 


\begin{tabular}{|c|c|c|c|}
\hline $\begin{array}{l}7 /(11 \text { de } \\
\text { febrero ) }\end{array}$ & $\begin{array}{l}\text { Responsabilidad extracontractual: violación } \\
\text { del deber general de diligencia y prudencia } \\
\text { - } \quad \text { Responsabilidad directa e indirecta } \\
\text { (responsabilidad extracontractual de } \\
\text { las personas jurídicas). }\end{array}$ & $\begin{array}{l}\text { 5A- GAMBOA, Juan Ignacio. El- } \\
\text { emento subjetivo - La culpa y el } \\
\text { dolo en la RC. } \\
\text { 7A- ZULETA, Alberto. Respon- } \\
\text { sabilidad civil extracontractual, } \\
\text { contractual y precontractual de } \\
\text { las personas jurídicas. } \\
\text { 7B- CSJ 12-05-1939. } \\
\text { 7C- CSJ 30-06-1947. } \\
\text { 7D- CSJ 20-04-1993. } \\
\text { 7E- CSJ 04-06-1992. } \\
\text { 7F- Hipertexto. }\end{array}$ & $\begin{array}{l}\text { Arts. } 2341-2360 \text { C. C. } \\
\text { Art. } 90 \text { Const. Política. } \\
\text { Ley } 678 \text { de } 2001 \text { (acción } \\
\text { de repetición). } \\
\text { Lectura y entrega del } \\
\text { caso (PBL 1) }\end{array}$ \\
\hline $\begin{array}{l}8 /(13 \mathrm{de} \\
\text { febrero) }\end{array}$ & $\begin{array}{l}\text { - } \quad \text { Responsabilidad por hechos de las } \\
\text { cosas. } \\
\text { - } \quad \text { Responsabilidad por actividades. } \\
\text { peligrosas. } \\
\text { Responsabilidad objetiva. }\end{array}$ & $\begin{array}{l}\text { 8A- CSJ 22-04-1997. } \\
\text { 8B- CSJ 06-04-1989. } \\
\text { 8C- CSJ 24-08-2009. } \\
\text { 8D- CSJ 26-08-2010. } \\
\text { 8E- CSJ 01-09-1960. } \\
\text { 8F- CE 13-02-2003. } \\
\text { 8G- CASTRO, Marcela. Respon- } \\
\text { sabilidad civil objetiva... } \\
\text { 8G- Hipertexto. }\end{array}$ & $\begin{array}{l}\text { Arts. } 2347-2356 \text { C.C. } \\
\text { Art } 90 \text { Const. Política. } \\
\text { Presentación del esque- } \\
\text { ma de planteamiento } \\
\text { del caso de la parte de- } \\
\text { mandante -convocante } \\
\text { (PBL1). } \\
\text { Taller jurisprudencia II. }\end{array}$ \\
\hline $\begin{array}{l}9 /(18 \mathrm{de} \\
\text { febrero) }\end{array}$ & \begin{tabular}{|l} 
Nexo causal: \\
$-\quad$ Causa eficiente. \\
$-\quad$ Equivalencia de condiciones. \\
- $\quad$ Concurrencia de causas y de culpas. \\
$\quad$ El daño indirecto.
\end{tabular} & $\begin{array}{l}\text { 9A- SUESCÚN, Jorge. Estudios \# } 9 \\
\text { 9B- ORTIZ, Gerardo. El nexo caus- } \\
\text { al en la responsabilidad civil. } \\
\text { 9C- SNG 01-09-60. } \\
\text { 9D- CSJ 09-02-76. } \\
\text { 9E- Hipertexto. }\end{array}$ & $\begin{array}{l}\text { Art. } 2341,2357 \text { del C. C. } \\
\text { Presentación del esque- } \\
\text { ma de planteamiento } \\
\text { del caso de la parte } \\
\text { demandada- convocada } \\
\text { (PBL 1). }\end{array}$ \\
\hline $\begin{array}{l}10 /(20 \\
\text { de fe- } \\
\text { brero) }\end{array}$ & $\begin{array}{l}\text { Causales de exoneración de responsabilidad } \\
\begin{aligned} \text { civil (causa extraña): } \\
-\quad \text { Fuerza mayor y caso fortuito. } \\
\text { - } \quad \text { Hecho de un tercero. } \\
\text { - } \quad \text { Hecho de la víctima. }\end{aligned}\end{array}$ & $\begin{array}{l}\text { 10A- CÁRDENAS, Juan Pablo. La } \\
\text { causa extraña como eximente de } \\
\text { responsabilidad. } \\
\text { 10B- ROMERO, Diego. Tratamien- } \\
\text { to jurisprudencial de la irresist- } \\
\text { ibilidad y la imprevisibilidad de la } \\
\text { fuerza mayor y el caso fortuito. } \\
\text { 10C- Hipertexto. }\end{array}$ & $\begin{array}{l}\text { Art. } 64 \text { C. C. } \\
\text { Arts. } 1127 \text { - } 1133 \text { C. Co. } \\
\text { Ley } 986 \text { de } 2005 . \\
\text { Taller jurisprudencia III. } \\
\text { Presentación acta de } \\
\text { misión tribunal de ar- } \\
\text { bitramento. }\end{array}$ \\
\hline $\begin{array}{l}11 /(25 \\
\text { de fe- } \\
\text { brero) }\end{array}$ & $\begin{array}{l}\text { Acciones de responsabilidad civil iure heredi- } \\
\text { tatis. Responsabilidad civil y responsabilidad } \\
\text { penal. }\end{array}$ & $\begin{array}{l}\text { 11A- SOLARTE, Arturo. Las accio- } \\
\text { nes iure hereditatis en la respon- } \\
\text { sabilidad civil. } \\
\text { 11B- CSJ 27-07-12. } \\
\text { 11C- SICUA+: Mapa conceptual } \\
\text { de la responsabilidad civil. } \\
\text { 11D- Hipertexto }\end{array}$ & $\begin{array}{l}\text { Audiencia de alegatos } \\
\text { (PBL 1). }\end{array}$ \\
\hline $\begin{array}{l}12 /(27 \\
\text { de fe- } \\
\text { brero) }\end{array}$ & & & $\begin{array}{l}\text { Audiencia de lectura de } \\
\text { laudo (PBL 1). } \\
\text { Quiz individual. Respon- } \\
\text { sabilidad civil. }\end{array}$ \\
\hline
\end{tabular}




\begin{tabular}{|c|c|c|c|}
\hline $\begin{array}{l}13 /(4 \text { de } \\
\text { marzo) }\end{array}$ & $\begin{array}{l}\text { EFECTOS DE LAS OBLIGACIONES. } \\
\text { La ejecución forzosa. Formas y casos de eje- } \\
\text { cución. Aspectos sustanciales y procesales. } \\
\text { Obligaciones de dar, hacer, no hacer. }\end{array}$ & $\begin{array}{l}\text { 13A-CASTRO, Marcela. El pat- } \\
\text { rimonio como prenda general y } \\
\text { derechos de los acreedores. } \\
\text { 13B- ROJAS, Miguel. Principales } \\
\text { derechos de los acreedores. } \\
\text { 13C- SICUA+: ejecución forzosa. } \\
\text { 13D- Hipertexto. }\end{array}$ & $\begin{array}{l}\text { Arts. } 488 \text { - } 512 \text { C. P. C. } \\
\text { Arts. } 422 \text { y siguientes } \\
\text { CGP. } \\
\text { Discusión. }\end{array}$ \\
\hline $\begin{array}{l}14 /(6 \text { de } \\
\text { marzo) }\end{array}$ & $\begin{array}{l}\text { Ejecución individual: título ejecutivo y medi- } \\
\text { das cautelares. Proceso ejecutivo singular/ } \\
\text { con garantía real. }\end{array}$ & $\begin{array}{l}\text { 14A-CANOSA, Ulises. Ejecución } \\
\text { individual. } \\
\text { 14B-SICUA+: proceso declarativo } \\
\text { - proceso ejecutivo. } \\
\text { 14C- Hipertexto. } \\
\end{array}$ & $\begin{array}{l}\text { Arts. 513-537; 554-555; } \\
\text { 681-684 CPC. } \\
\text { Discusión. }\end{array}$ \\
\hline $\begin{array}{l}\text { 15/ (11 } \\
\text { de mar- } \\
\text { zo) }\end{array}$ & Ejecución colectiva. Liquidación. & $\begin{array}{l}\text { 15A- CUBEROS, Gustavo. Eje- } \\
\text { cución colectiva y procesos con- } \\
\text { cursales. } \\
\text { 15B- Hipertexto. }\end{array}$ & $\begin{array}{l}\text { Arts. } 2488 \text { - } 2511 \text { C. C. } \\
\text { Ley } 1116 \text { de } 2006 .\end{array}$ \\
\hline $\begin{array}{l}\text { 16/ (13 } \\
\text { de mar- } \\
\text { zo) }\end{array}$ & $\begin{array}{l}\text { Prelación de créditos. } \\
\text { Régimen de insolvencia empresarial. }\end{array}$ & $\begin{array}{l}\text { 16A- ALESSANDRI, Arturo. La } \\
\text { prelación de créditos } \\
\text { 16B- Hipertexto. }\end{array}$ & $\begin{array}{l}\text { Arts. } 2488 \text { - } 2511 \text { C. C. } \\
\text { Ley } 1116 \text { de } 2006 . \\
\text { Presentación de crédi- } \\
\text { tos - Ejercicio de liq- } \\
\text { uidación judicial - 1ạ } \\
\text { parte. }\end{array}$ \\
\hline $\begin{array}{l}\text { 17/ (18 } \\
\text { de mar- } \\
\text { zo) }\end{array}$ & $\begin{array}{l}\text { Indemnización de perjuicios: compensatorios } \\
\text { y moratorios. Mora debitoria. } \\
\text { Derecho auxiliares de los acreedores. Patri- } \\
\text { monio como prenda general. Medidas con- } \\
\text { servatorias: comunes y especiales. Derecho } \\
\text { de retención. }\end{array}$ & $\begin{array}{l}\text { 17A- RAMÍREZ, Edgar. Indemni- } \\
\text { zación compensatoria y morato- } \\
\text { ria de perjuicios. } \\
\text { 17B- CASTRO, Marcela. El dere- } \\
\text { cho de retención. } \\
\text { 17C- Hipertexto. }\end{array}$ & $\begin{array}{l}\text { Arts. 1608, 1615, 1546, } \\
2417 \text { C. C. } \\
\text { Art. } 870 \text { C. Co. } \\
\text { Auto de graduación de } \\
\text { créditos - Ejercicio de } \\
\text { liquidación judicial - 2ạ } \\
\text { parte. }\end{array}$ \\
\hline $\begin{array}{l}\text { 18/ }(20 \\
\text { de mar- } \\
\text { zo) }\end{array}$ & $\begin{array}{l}\text { Medidas reconstitutivas del patrimonio del } \\
\text { deudor. }\end{array}$ & $\begin{array}{l}\text { 18A- PÁJARO, Nicolás. Las accio- } \\
\text { nes reconstitutivas del patrimo- } \\
\text { nio del deudor. } \\
\text { 18B- Hipertexto. }\end{array}$ & $\begin{array}{l}\text { Arts. } 2491 \text { y } 1766 \text { C. C. } \\
\text { Ley } 1116 \text { de } 2006 . \\
\text { Art. } 407 \text { C. P. C. } \\
\text { Discusión. } \\
\end{array}$ \\
\hline \multicolumn{4}{|c|}{ SEMANA DE TRABAJO INDIVIDUAL } \\
\hline $\begin{array}{l}19 /(1 \mathrm{de} \\
\text { abril) }\end{array}$ & $\begin{array}{l}\text { TRANSMISIÓN DE LAS OBLIGACIONES. } \\
\text { Transmisión a título universal y singular. In- } \\
\text { tervivos y mortis causa. }\end{array}$ & $\begin{array}{l}\text { 19A- CASTRO, Marcela. Transmis- } \\
\text { ión de las obligaciones - Visión } \\
\text { panorámica y plan de trabajo. } \\
\text { 19B- CASTRO, Marcela. Trans- } \\
\text { misión de las obligaciones mortis } \\
\text { causa. } \\
\text { 19C- Hipertexto. } \\
\end{array}$ & $\begin{array}{l}\text { Art. } 1008 \text { C. C. } \\
\text { Ejercicio en clase } \\
\text { Preguntas hipertexto }\end{array}$ \\
\hline $\begin{array}{l}20 / \text { (3 de } \\
\text { abril) }\end{array}$ & Cesión de créditos y de deudas. & $\begin{array}{l}\text { 20A-CASTRO, Marcela. La cesión } \\
\text { de créditos. } \\
\text { 20B- CASTRO, Marcela. Transmis- } \\
\text { ión de deudas. } \\
\text { 20C- Hipertexto. }\end{array}$ & $\begin{array}{l}\text { Arts. } 1959-1968 \text { C. C. } \\
\text { Preguntas hipertexto. }\end{array}$ \\
\hline
\end{tabular}

31 ALESSANDRI, Arturo. La prelación de créditos: explicaciones de clases. Santiago de Chile: Editorial Nascimento, 1940. 


\begin{tabular}{|c|c|c|c|}
\hline $\begin{array}{l}21 / \text { ( } 8 \text { de } \\
\text { abril) }\end{array}$ & $\begin{array}{l}\text { Cesión de derechos litigiosos. } \\
\text { Transferencia de títulos valores. } \\
\text { Cesión de posición contractual. }\end{array}$ & $\begin{array}{l}\text { 21A- CASTRO, Marcela. Cesión } \\
\text { de derechos litigiosos. } \\
\text { 21B- CASTRO, Marcela. La cesión } \\
\text { de contratos. } \\
\text { 21C- Hipertexto. } \\
\end{array}$ & $\begin{array}{l}\text { Arts. } 1969 \text {-1972 C. C. } \\
\text { Ejercicio en clase. } \\
\text { Preguntas hipertexto. }\end{array}$ \\
\hline $\begin{array}{l}22 /(10 \\
\text { de abril) }\end{array}$ & $\begin{array}{l}\text { Enajenación de universalidades (estableci- } \\
\text { miento de comercio). } \\
\text { Transferencias patrimoniales en bloque. } \\
\text { Fusión y escisión de sociedades. }\end{array}$ & $\begin{array}{l}\text { 22A- CASTRO, Marcela. Trans- } \\
\text { misión de universalidades. } \\
\text { 22B- Hipertexto. }\end{array}$ & $\begin{array}{l}\text { Arts. 515, 516, 525-533; } \\
\text { 172-180 C.Co. } \\
\text { Ley } 222 \text { de 1995: Arts. } \\
\text { 3-11. } \\
\text { Preguntas hipertexto. }\end{array}$ \\
\hline $\begin{array}{l}23 /(15 \\
\text { de abril) }\end{array}$ & \multicolumn{3}{|c|}{ PARCIAL TRANSMISIÓN Y EFECTOS DE LAS OBLIGACIONES (por SICUA+) } \\
\hline $\begin{array}{l}24 /(17 \\
\text { de abril) }\end{array}$ & $\begin{array}{l}\text { EXTINCIÓN DE LAS OBLIGACIONES. } \\
\text { De los modos de extinguirse las obligaciones. } \\
\text { El pago. }\end{array}$ & $\begin{array}{l}\text { 24A- ROMERO, Diego. Extinción } \\
\text { de las obligaciones - Visión pan- } \\
\text { orámica y plan de trabajo. } \\
\text { 24B- CASTRO, Marcela. El pago o } \\
\text { cumplimiento. } \\
\text { 24C- CASTRO, Marcela. La sub- } \\
\text { rogación. } \\
\text { 24D- REMOLINA ANGARITA, } \\
\text { Nelson. Pago con títulos-valores } \\
\text { de contenido crediticio. } \\
\text { 24D- Hipertexto. }\end{array}$ & $\begin{array}{l}\text { Arts. } 1625-1686 \text { C. C } \\
\text { Arts. } 873-886 \text { C. Co. } \\
\text { Preguntas hipertexto. }\end{array}$ \\
\hline $\begin{array}{l}25 /(22 \\
\text { de abril) }\end{array}$ & $\begin{array}{l}\text { La novación. } \\
\text { La compensación. }\end{array}$ & $\begin{array}{l}\text { 25A- CASTRO, Marcela y ROME- } \\
\text { RO, Diego. La novación. } \\
\text { 25B- GAMBOA, Mario. La com- } \\
\text { pensación. } \\
\text { 25C- Hipertexto. }\end{array}$ & $\begin{array}{l}\text { Arts. } 1687 \text { - 1710, } 1714 \\
\text { - } 1723 \text { C. C. } \\
\text { Preguntas hipertexto. } \\
\text { PBL - Sesión } 1 .\end{array}$ \\
\hline $\begin{array}{l}26 /(24 \\
\text { de abril) }\end{array}$ & $\begin{array}{l}\text { La transacción. } \\
\text { La remisión. }\end{array}$ & $\begin{array}{l}\text { 26A- JARAMILLO, Carlos Ignacio. } \\
\text { La transacción. } \\
\text { 26B- CASTRO, Marcela. La re- } \\
\text { misión. } \\
\text { 26C- Hipertexto. }\end{array}$ & $\begin{array}{l}\text { Arts. } 2469 \text { - 2487, } 1711 \\
\text { - } 1713 \text { C. C. } \\
\text { Preguntas hipertexto. }\end{array}$ \\
\hline $\begin{array}{l}27 /(29 \\
\text { de abril) }\end{array}$ & $\begin{array}{l}\text { La confusión. } \\
\text { La prescripción liberatoria. }\end{array}$ & $\begin{array}{l}\text { 27A- CASTRO, Marcela. La con- } \\
\text { fusión. } \\
\text { 27B- CASTRO, Marcela. La pre- } \\
\text { scripción liberatoria. } \\
\text { 27C- Hipertexto. } \\
\end{array}$ & $\begin{array}{l}\text { Arts. 1724-1728, 2512- } \\
\text { 2517, } 2535 \text { - } 2545 \text { C. C. } \\
\text { Preguntas hipertexto. } \\
\text { PBL - Sesión } 2 .\end{array}$ \\
\hline $\begin{array}{l}28 /(6 \text { de } \\
\text { mayo) }\end{array}$ & $\begin{array}{l}\text { La imposibilidad de ejecución: pérdida de } \\
\text { la cosa, muerte del deudor o del acreedor. } \\
\text { Prestación imposible por fuerza mayor o caso } \\
\text { fortuito. }\end{array}$ & $\begin{array}{l}\text { 28A- CASTRO, Marcela. La impo- } \\
\text { sibilidad de la ejecución. } \\
\text { 28B- Hipertexto. }\end{array}$ & $\begin{array}{l}\text { Arts. } 1729 \text { a } 1739, \\
\text { 1607, } 1876,1740-1756 \\
\text { C. C. } \\
\text { Art. } 929 \text { C. Co. } \\
\text { Preguntas hipertexto. }\end{array}$ \\
\hline $\begin{array}{l}29 /(8 \mathrm{de} \\
\text { mayo) }\end{array}$ & $\begin{array}{l}\text { Modos indirectos: declaratoria de nulidad, la } \\
\text { convención extintiva, la condición resolutoria, } \\
\text { revocación unilateral, declaración judicial, } \\
\text { simulación. }\end{array}$ & $\begin{array}{l}\text { 29A- CASTRO, Marcela y ROME- } \\
\text { RO, Diego. Otros modos de ex- } \\
\text { tinción de las obligaciones. } \\
\text { 29B- CSJ 14-12-2010. } \\
\text { 29C- Hipertexto. }\end{array}$ & $\begin{array}{l}\text { Arts. } 1536 \text { - } 1546 \text { C. C. } \\
\text { Arts. 899-904 C. Co. } \\
\text { Preguntas hipertexto. }\end{array}$ \\
\hline
\end{tabular}

Examen final: fecha señalada por Admisiones y Registro.

Nota: por los días festivos, podrán requerirse sesiones adicionales para cubrir el programa con la intensidad horaria requerida. 
ANEXO 2: PBL - JUEGO DE ROLES TRIBUNAL ARBITRAL

\section{UN VIAJE SIN REGRESO}

Armando Puentes y su esposa Ana tienen un negocio muy próspero de agencia de viajes, cuya actividad se ha extendido a la organización de planes vacacionales, excursiones y a la prestación de todo tipo de asesorías y servicios relacionados con el turismo, a través de su establecimiento de comercio denominado "Nadie te quita lo viajado".

Para remodelar su nueva sede en Cali contrataron a la firma de ingenieros "Profesionales en Construcción S. A." (en adelante PC) para elaborar los diseños y posteriormente realizar la obra. PC tiene como socios a Juan Cuadrado, primo de Armando, y María del Hierro, cada uno con el $50 \%$ de las acciones. Juan actúa como gerente de la compañía.

En enero del año pasado Armando y Ana, por un lado, y Juan como representante legal de PC, por el otro, suscribieron un contrato a precio global fijo por $\$ 80$ millones para adecuar el inmueble, precio que se pagaría $30 \%$ como anticipo a la firma del contrato y el saldo a la entrega a satisfacción de la obra. Esta duraría dos meses a partir de la firma del contrato. Armando le comunicó a Juan que en marzo tenía previsto terminar el trasteo al nuevo sitio y en abril comenzaría la operación de su negocio en el local remodelado, justo a tiempo para la intensa temporada de vacaciones de mitad de año cuyas ventas le reportaban ganancias considerables.
Juan le aseguró que la obra estaría terminada a tiempo pero que por seguridad nadie podía entrar a la obra sin su previa autorización y, en todo caso, debía emplearse el casco protector.

En el contrato se pactaron las siguientes cláusulas:

SEXTA: PC no se hace responsable de daños que sufra el CONTRATANTE por hechos dolosos o gravemente culposos que sus empleados 0 subcontratistas realicen en desconocimiento de las instrucciones impartidas por PC.

DECIMA: Las partes acuerdan someter a arbitraje todas las controversias que surjan de este contrato. El tribunal estará conformado por tres árbitros que fallarán en derecho y que serán designados de común acuerdo o por el Centro de Arbitraje y Conciliación de la Cámara de Comercio de Cali.

Todo empezó muy bien: Armando y Ana pagaron el anticipo y la obra comenzó sin contratiempos. Sin embargo, esta registró atrasos cada vez mayores, según Juan porque había una escasez de cemento y otros materiales por el boom de la construcción, lo cual a su vez hizo incrementar notablemente los precios. Para acelerar los trabajos, PC aumentó el número de sus empleados en la obra y subcontrató dos firmas especializadas en arquitectura que no fueron presupuestadas inicialmente; una para obras de mampostería (Ladrillos y Muros E. U. en adelante "LyM") y otra para redes hidráulicas y eléctricas (HidroElec Ltda.). No obstante, la obra ya mostraba una demora considerable; llegado el mes 
de septiembre no estaba concluida y al hacer cuentas Juan llegó a la conclusión que por todas estas circunstancias la obra iba a costar 20\% más de lo previsto.

Por deficiente instalación por parte de Hidroelec, se produjo la ruptura de un tubo de agua que generó humedad en una pared medianera con la casa vecina, de propiedad de Roberto, humedad que se filtró también por el piso. Roberto había arrendado la casa a Mónica para depositar materias primas para textiles, que por la humedad se deterioraron hasta perderse totalmente. Mónica ha reclamado a Armando y a Ana verbalmente y por escrito el valor de los materiales por cuya pérdida debió conseguir otros en el mercado, a precios muy superiores.

Una noche Armando entró al inmueble en busca de unos documentos y sorprendió a Francisco, joven empleado de PC, huyendo con computa- dores y elementos de oficina de propiedad de Armando, y que este había dejado en un cuarto con llave. Francisco logró huir y aunque Armando notificó a la Policía, aquel no pudo ser localizado ni los elementos recuperados. Muy preocupado, Armando se recostó contra un muro que acababa de construir LyM, con tan mala suerte que tras un temblor de 4.0 en la escala de Richter el muro se derrumbó sobre Armando arrastrando a su paso varios elementos pesados. Armando no solo quedó sepultado bajo los escombros, sino que recibió un golpe en la nuca que le causó la muerte. Héctor, amigo de Armando y experto en construcción, revisó los escombros y le dijo a la apesadumbrada viuda que los materiales del muro eran de mala calidad y que la técnica de construcción había sido deficiente.

Ana y sus dos hijos menores consultaron a su abogado, quien les recomendó instaurar una demanda. 


\section{ANEXO 3: MATRIZ DE CALIFICACIÓN - \\ PBL 1: PROCESO ARBITRAL DE RESPONSABILIDAD CIVIL}

Formato 1- Esquema demandante

\begin{tabular}{|c|c|c|}
\hline Criterio & $\begin{array}{l}\text { Puntaje } \\
\text { máximo }\end{array}$ & $\begin{array}{l}\text { Puntaje } \\
\text { obtenido }\end{array}$ \\
\hline 1. El escrito evidencia conocimiento de los hechos relevantes. & 10 & \\
\hline $\begin{array}{l}\text { 2. Se identifican de manera correcta y completa las instituciones jurídicas } \\
\text { involucradas. }\end{array}$ & 20 & \\
\hline 3. Se formulan adecuadamente las pretensiones. & 20 & \\
\hline 4. Se identifican las fuentes jurídicas aplicables. & 20 & \\
\hline $\begin{array}{l}\text { 5. El texto es completo y coherente. El documento está bien redactado en } \\
\text { términos de vocabulario jurídico, ortografía, gramática y sintaxis. }\end{array}$ & 20 & \\
\hline 6. La presentación oral fue ordenada y coherente. & 10 & \\
\hline TOTAL: & 100 & \\
\hline \multicolumn{3}{|l|}{ OBSERVACIONES: } \\
\hline $\begin{array}{l}\text { Fecha: } \\
\text { Firma del profesor: }\end{array}$ & & \\
\hline
\end{tabular}

\section{ANEXO 4: MATRIZ DE CALIFICACIÓN - \\ PBL 1: PROCESO ARBITRAL DE RESPONSABILIDAD CIVIL}

Formato 2- Esquema demandado

\begin{tabular}{|c|c|c|}
\hline Criterio & $\begin{array}{l}\text { Puntaje } \\
\text { máximo }\end{array}$ & $\begin{array}{l}\text { Puntaje } \\
\text { obtenido }\end{array}$ \\
\hline 1. El escrito evidencia conocimiento de los hechos relevantes. & 10 & \\
\hline $\begin{array}{l}\text { 2. Se identifican de manera correcta y completa las instituciones jurídicas } \\
\text { involucradas. }\end{array}$ & 20 & \\
\hline 3. Se formulan adecuadamente las excepciones. & 20 & \\
\hline 4. Se identifican las fuentes jurídicas aplicables. & 20 & \\
\hline $\begin{array}{l}\text { 5. El texto es completo y coherente. El documento está bien redactado en } \\
\text { términos de vocabulario jurídico, ortografía, gramática y sintaxis. }\end{array}$ & 20 & \\
\hline 6. La presentación oral fue ordenada y coherente. & 10 & \\
\hline TOTAL: & 100 & \\
\hline \multicolumn{3}{|l|}{ OBSERVACIONES: } \\
\hline $\begin{array}{l}\text { Fecha: } \\
\text { Firma del profesor: }\end{array}$ & & \\
\hline
\end{tabular}




\section{ANEXO 5: MATRIZ DE CALIFICACIÓN - \\ PBL 1: PROCESO ARBITRAL DE RESPONSABILIDAD CIVIL}

Formato 3- Acta de misión (tribunal arbitral)

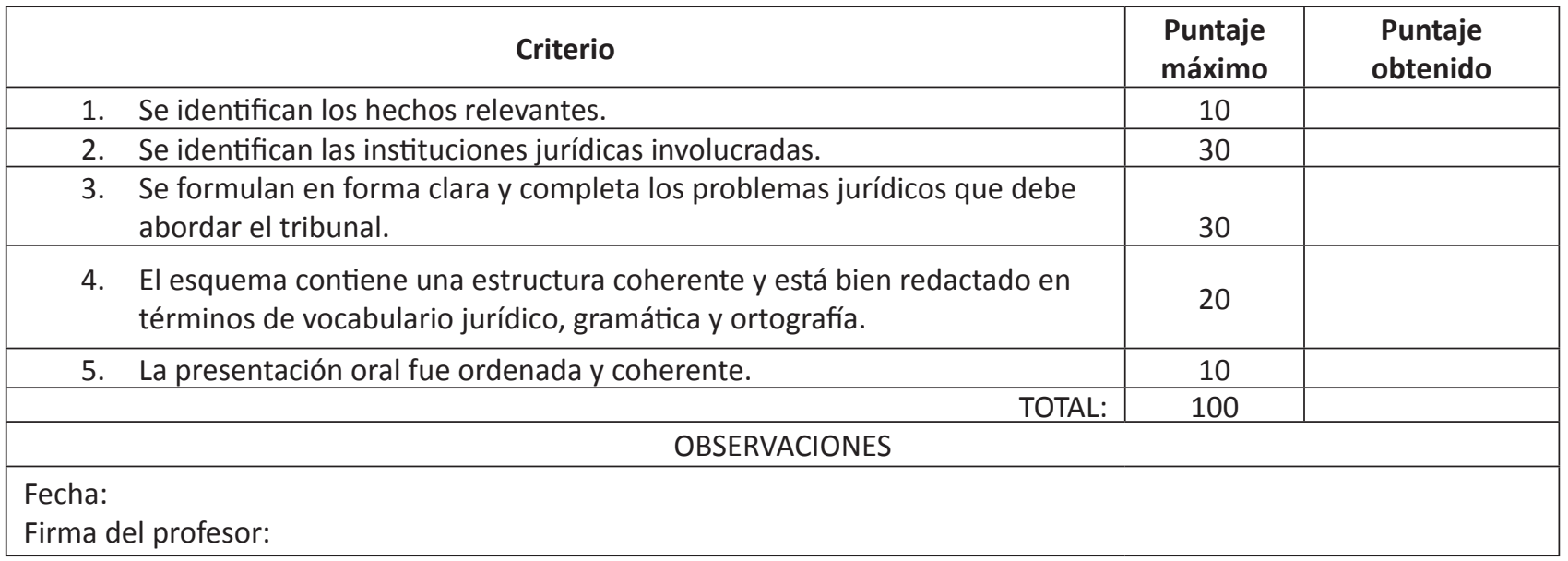

\section{ANEXO 6: MATRIZ DE CALIFICACIÓN - \\ PBL 1: PROCESO ARBITRAL DE RESPONSABILIDAD CIVIL}

Formato 4- Alegatos parte demandante

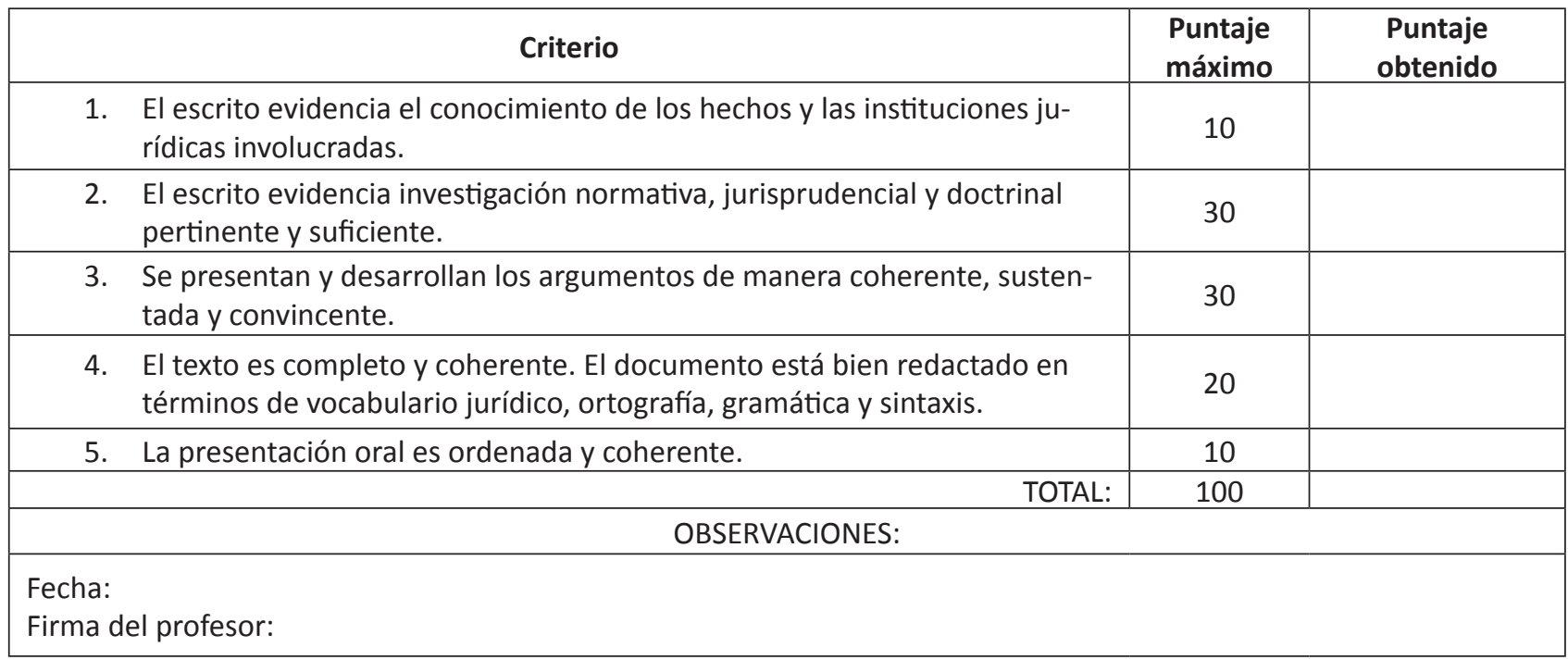




\section{ANEXO 7: MATRIZ DE CALIFICACIÓN - \\ PBL 1: PROCESO ARBITRAL DE RESPONSABILIDAD CIVIL}

Formato 5- Alegatos parte demandada

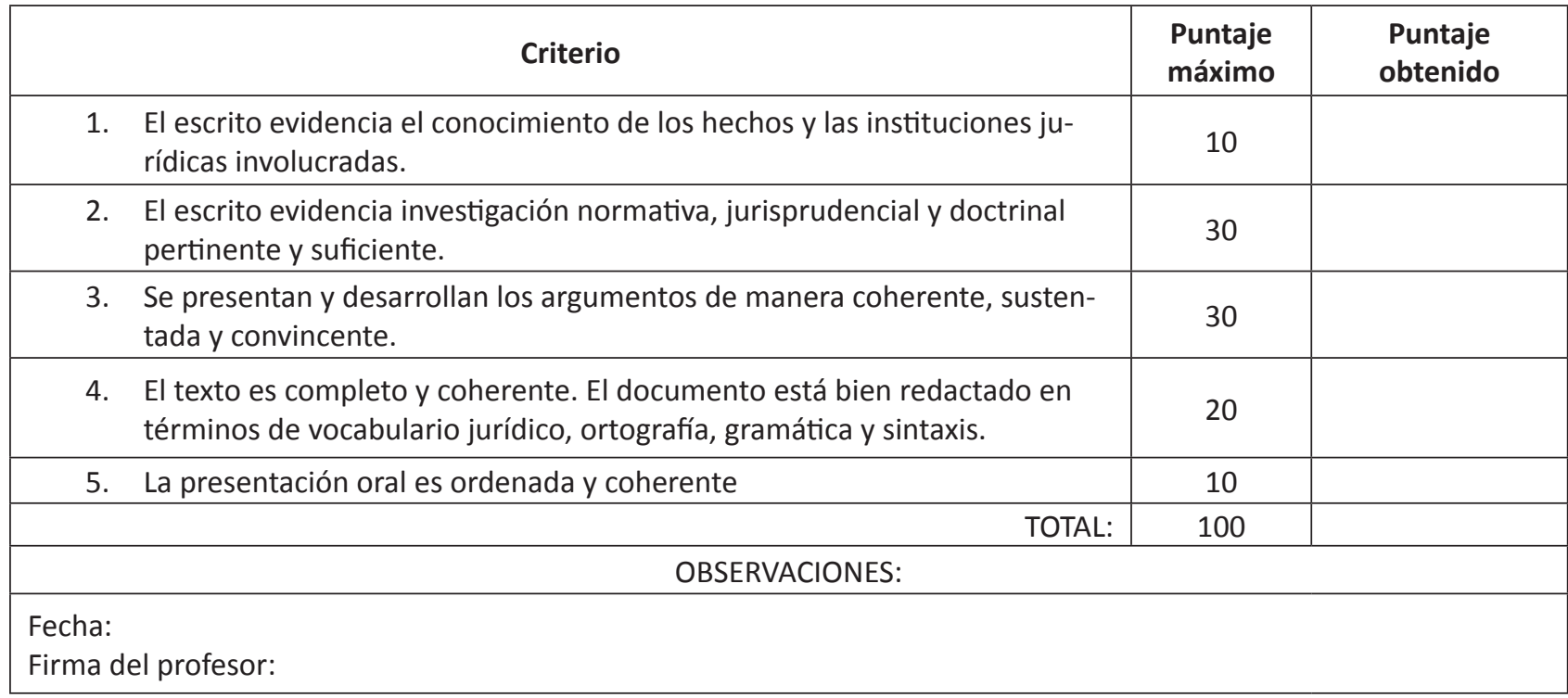

\section{ANEXO 8: MATRIZ DE CALIFICACIÓN - \\ PBL 1: PROCESO ARBITRAL DE RESPONSABILIDAD CIVIL}

Formato 6- Laudo arbitral

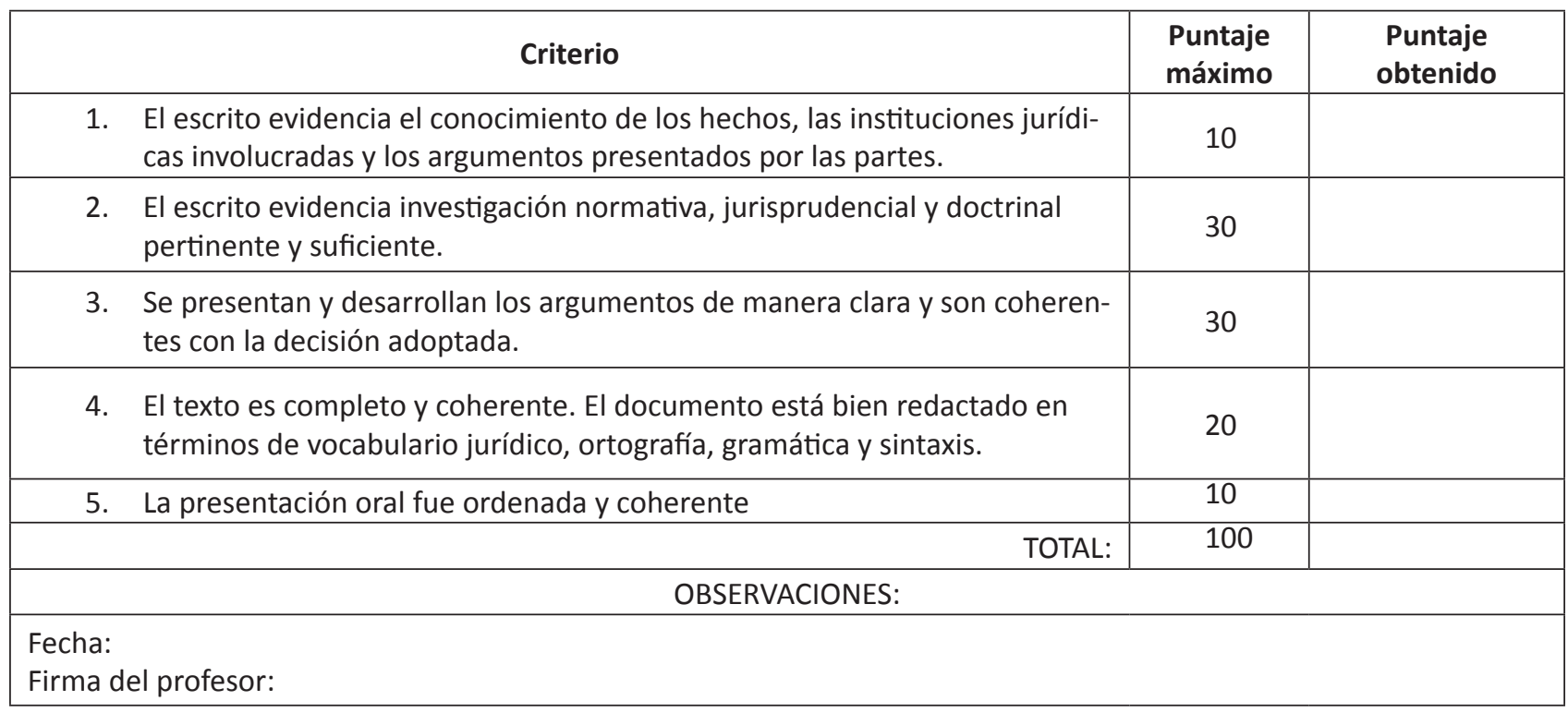




\section{ANEXO 9: CIFRAS E INSTRUCCIONES DE LA SIMULACIÓN "CREACIONES MODERNAS"}

NOTA IMPORTANTE: Para este ejercicio es indispensable que todos los alumnos:

a) Conozcan la historia que aparece en 16 escenas en Sicuat.

b) Conozcan la legislación aplicable (normas aplicables del Código Civil y Ley 1116 de 2006, en los artículos pertinentes) y hagan previamente las lecturas asignada para los temas: procesos concursales, liquidación judicial, prelación de créditos.

Información adicional:

- La fábrica se encuentra localizada en el municipio de Chía

- Mario y Juana López, los socios mayoritarios de la compañía, cada uno tiene una participación del 35\% del capital social. El restante 30\% es de propiedad de otros hermanos.

Hoy en día la situación es la siguiente:

Mario tiene una casa en La Calera, avaluada en \$500 millones, hipotecada por él a favor del Banco del Comerciante para garantizar un préstamo otorgado a la sociedad por valor de \$250 millones

La sociedad:

- Es dueña del inmueble donde funciona la planta, con un valor de $\$ 1500$ millones, hi- potecado a favor del Banco del Empresario garantizando un préstamo de $\$ 800$ millones que utilizaron para ampliar la fábrica

- Tiene un camión para transportar productos entre Chía y Bogotá, avaluado en \$ 110 millones, pignorado con prenda sin tenencia a favor del Banco Solidario para garantizar una deuda cuyo saldo actual es de $\$ 75$ millones contraída para la compra del vehículo.

- Para la adquisición de la maquinaria industrial por valor de $\$ 700$ millones, la sociedad celebró un contrato de leasing financiero con la compañía Leasing Empresarial S. A., a la cual debe $\$ 480$ millones por concepto de cánones atrasados. Mario firmó el correspondiente pagaré como representante legal y también a nombre propio, como deudor solidario de la sociedad.

- Tiene en caja, inversiones de corto plazo y bancos $\$ 10.000 .000$ y en cuentas por cobrar a varios clientes $\$ 35$ millones

- El inventario de materia prima y productos terminados vale $\$ 100$ millones

- La marca "Moda Novedosa" tiene un valor en libros de $\$ 20$ millones.

- Debe \$210 millones en impuestos de renta y predial

- Debe $\$ 120$ millones en salarios a sus trabajadores, \$25 millones en aportes al Seguro Social y $\$ 85$ millones por concepto de indemnizaciones a trabajadores despedidos sin justa causa 
- A varios proveedores de materias primas debe $\$ 640$ millones

- En servicios públicos de agua, luz y teléfono debe $\$ 92$ millones

- A Seguros Universal debe $\$ 78$ millones por primas de seguros de incendio y terrorismo

- A varios compadres, familiares y amigos debe \$430 millones representados en varios pagarés, tres de los cuales por valor de $\$ 60$ millones se vencen en tres meses. Los dos hermanos López firmaron como codeudores solidarios de la sociedad Creaciones Modernas Ltda.

- En la Superintendencia de Sociedades se abrió el proceso concursal a la sociedad deudora a la cual acudirán todos los acreedores para hacer efectivos sus créditos. Ante el incumplimiento del acuerdo de reorganización suscrito, se procederá a la liquidación judicial de su patrimonio.

En este ejercicio debe:

a) Documentarse los diferentes créditos y las garantías, cuando las haya b) Reconocerse y graduarse los créditos, aplicando la prelación legal

c) Calcular las cantidades a pagar a los diferentes acreedores.

Para ello, se requiere la conformación de 10 grupos, cada uno de los cuales deberá:

a) Primera parte del ejercicio: elaborar documentos para presentar al proceso concursal liquidatorio en representación del respectivo acreedor (original y copia). Incluye el memorial de solicitud con los fundamentos de hecho y de derecho y los anexos requeridos (Poder, etc.)

b) Segunda parte del ejercicio: actuar como Superintendencia de Sociedades, profiriendo un auto de graduación de créditos, indicando las sumas a pagar a cada uno de los acreedores.

Anexo: matrices con criterios de evaluación 


\section{ANEXO 10: MATRIZ DE CALIFICACIÓN \\ - EJERCICIO DE LIQUIDACIÓN \\ JUDICIAL}

(prelación de créditos)

Formato 1- Presentación del crédito

\begin{tabular}{|c|c|c|}
\hline Criterio & $\begin{array}{l}\text { Puntaje } \\
\text { máximo }\end{array}$ & $\begin{array}{l}\text { Puntaje } \\
\text { obtenido }\end{array}$ \\
\hline $\begin{array}{l}\text { 7. El memorial de solicitud contiene y expresa de manera clara y correcta los ante- } \\
\text { cedentes fácticos, lo que se pretende y los fundamentos de derecho en que se } \\
\text { sustenta. }\end{array}$ & 30 & \\
\hline $\begin{array}{l}\text { 8. Se identifica correctamente la clase a la que pertenece el crédito presentado, } \\
\text { dentro de la prelación legal. }\end{array}$ & 10 & \\
\hline 9. Se presentan con el memorial los anexos necesarios (poder, prueba del crédito). & 20 & \\
\hline $\begin{array}{l}\text { 10. El memorial se redacta correctamente en términos de estructura, vocabulario } \\
\text { jurídico, redacción, gramática y ortografía. }\end{array}$ & 30 & \\
\hline 11. La presentación oral es clara y convincente. & 10 & \\
\hline TOTAL: & 100 & \\
\hline \multicolumn{3}{|l|}{ OBSERVACIONES: } \\
\hline $\begin{array}{l}\text { Fecha: } \\
\text { Firma del profesor: }\end{array}$ & & \\
\hline
\end{tabular}

\section{ANEXO 11. MATRIZ DE CALIFICACIÓN - EJERCICIO DE LIQUIDACIÓN JUDICIAL}

(prelación de créditos)

Formato 2- Documento de graduación y pago

\begin{tabular}{|c|c|c|}
\hline \multicolumn{1}{|c|}{ Criterio } & $\begin{array}{c}\text { Puntaje } \\
\text { máximo }\end{array}$ & $\begin{array}{c}\text { Puntaje } \\
\text { obtenido }\end{array}$ \\
\hline $\begin{array}{l}\text { 1. } \\
\text { El documento plantea de manera clara y ordenada los elementos fácticos nec- } \\
\text { esarios para realizar la graduación. }\end{array}$ & 20 \\
\hline $\begin{array}{l}\text { El documento presenta rigurosamente las consideraciones jurídicas y las fuentes } \\
\text { normativas necesarias para realizar la graduación (incluso observaciones sobre } \\
\text { deficiencias en los créditos presentados). }\end{array}$ & 20 \\
\hline $\begin{array}{l}\text { El documento contiene específicamente la graduación de créditos conforme a la } \\
\text { prelación legal. }\end{array}$ & 20 \\
\hline $\begin{array}{l}\text { El documento señala, en forma clara y conforme a los criterios legales, las sumas } \\
\text { a pagar a los distintos acreedores. }\end{array}$ & 20 \\
\hline $\begin{array}{l}\text { El documento se redacta correctamente en términos de estructura, vocabulario } \\
\text { jurídico, redacción, gramática y ortografía. }\end{array}$ & 20 \\
\hline \multicolumn{1}{|c|}{ TOTAL: } & 100 \\
\hline $\begin{array}{l}\text { Fecha: } \\
\text { Firma del profesor: }\end{array}$ & 20 \\
\hline
\end{tabular}


ANEXO 12: LAUDO ARBITRAL (JUICIO DE RESPONSABILIDAD CIVIL). CASO: UN VIAJE SIN REGRESO

TRIBUNAL DE ARBITRAMENTO ANA DE PUENTES, EN REPRESENTACIÓN DE SI MISMA Y SUS DOS HIJOS Vs. JUAN CUADRADO GERENTE DE PROFESIONALES EN CONSTRUCCIÓN S.A.S.

\section{LAUDO ARBITRAL}

\section{A.- ANTECEDENTES:}

Armando Puentes y su esposa Ana, dueños del establecimiento comercial "nadie te quita lo viajado", suscribieron un contrato para remodelar la nueva sede en Cali con la firma de ingenieros "Profesionales en Construcción S.A.S" (en adelante PC), la cual tiene como socios a Juan Cuadrado, gerente de la misma; y María del Hierro. El contrato tenía un precio de $\$ 150.000 .000$. oo, el cual sería pagado de la siguiente manera: $30 \%$ como anticipo en el momento de la firma del contrato, y el 70\% restante una vez culminada la obra. La obra en un principio duraría dos meses, termino en el cual Juan haría le trasteo para empezar a operar en abril. Sin embargo, la obra presento atrasos, debido a la escasez de materiales y otros materiales. A raíz de este atraso, PC subcontrato a HidroElec y "Ladrillos y Muros E.U." (LyM), para acelerar el proceso de construcción. Para el mes de septiembre, la obra aún no estaba terminada, concluyendo Juan que la obra iba a costar un 20\% más de lo pactado. Debido a una mala instalación de un tubo de agua por parte HidroElec, este se rompió generando humedad en la pared que co- lindaba con el local de Mónica, quien a raíz de esto perdió materias primas textiles. Una noche Armando entro al local y sorprendió a Francisco, un empleado de PC, robando unos computadores y elementos de la oficina, no se pudo detener al delincuente ni recuperar los elementos. Después de este incidente, Armando se recostó en un muro construido por LyM que tras un temblor de 4.0 en la escala de Richter colapso, matando a Armando. En el contrato se estipuló una cláusula en la que se acordó que todas las controversias que surgieran a partir del proceso serian sometidas a arbitraje y más adelante se suscrbió un documento denominado "COMPROMISO", en el que las partes se obligaron a someter a la decisión de árbitros todas las controversias surgidas con ocasión a los hechos.

\section{B.- COMPETENCIA:}

En virtud del artículo 116, inciso $4^{\circ}$ de la Constitución Política de Colombia, se puede investir a los particulares de la facultad de administrar justicia de manera transitoria, "en la condición de conciliadores o en la de árbitros habilitados por las partes, para proferir fallos en derecho o en equidad, en los términos que determine la ley".

De esta manera, la Ley 446 de 1998', en su artículo 66 establece los asuntos conciliables, siendo éstos "todos los asuntos susceptibles de

"Por la cual se adoptan como legislación permanente algunas normas del Decreto 2651 de 1991, se modifican algunas del Código de Procedimiento Civil, se derogan otras de la Ley 23 de 1991 y del Decreto 2279 de 1989, se modifican y expiden normas del Código Contencioso Administrativo y se dictan otras disposiciones sobre descongestión, eficiencia y acceso a la justicia." 
transacción, desistimiento y aquellos que expresamente determine la ley" (artículo $2^{\circ}$ Decreto 1818 de 1998).

Considerando lo anteriormente expuesto, el Centro de Arbitraje y Conciliación de la Cámara de Comercio de Cali, tiene la facultad de designar tres de sus árbitros para que éstos tengan conocimiento de las controversias surgidas del contrato celebrado por las partes. Así, partiendo también del artículo 3" de la Ley 1563 de $2012^{\prime \prime \prime}$, el cual se refiere al pacto arbitral establecido por las partes en el contrato, el tribunal de arbitramento tiene capacidad para conocer el proceso adelantado por Ana de Puentes contra Profesionales en Construcción S.A.S. -PC-, ya que dicho pacto fue estipulado en la cláusula décima del contrato celebrado por las partes, cuyo texto es el siguiente:

DECIMA: Las partes acuerdan someter a arbitraje todas las controversias que surjan de este contrato. El tribunal estará conformado por tres árbitros que fallarán en derecho y que serán designados de común acuerdo o por el Centro de Arbitraje de la Cámara de Comercio de Cali.

II Artículo $3^{\circ}$. Pacto arbitral. El pacto arbitral es un negocio jurídico por virtud del cual las partes someten o se obligan a someter a arbitraje controversias que hayan surgido o puedan surgir entre ellas.

El pacto arbitral implica la renuncia de las partes a hacer valer sus pretensiones ante los jueces. El pacto arbitral puede consistir en un compromiso o en una cláusula compromisoria.

En el pacto arbitral las partes indicarán la naturaleza del laudo. Si nada se estipula al respecto, este se proferirá en derecho.

Parágrafo. Si en el término de traslado de la demanda, o de su contestación, o de las excepciones previas, una parte invoca la existencia de pacto arbitral y la otra no la niega expresamente, ante los jueces o el tribunal de arbitraje, se entiende válidamente probada la existencia de pacto arbitral

"Por medio de la cual se expide el Estatuto de Arbitraje Nacional e Internacional y se dictan otras disposiciones."
La controversia se decidirá de conformidad con la ley colombiana.

Por otro lado, en cuanto a la competencia del Tribunal para referirse sobre las pretensiones extracontractuales, ésta se ve fundamentada en el Compromiso firmado por las partes, en el cual éstas se obligaron a someter a la decisión de árbitros todas las controversias surgidas con ocasión de los hechos presentados. Todo lo anterior, se encuentra fundamentado en el artículo 117 del Decreto 1818 de 1998, en el cual se establece que "por medio del pacto arbitral, que comprende la cláusula compromisoria y el compromiso, las partes se obligan a someter sus diferencias a la decisión de un Tribunal Arbitral, renunciando a hacer valer sus pretensiones ante los jueces".

\section{C.- ÁRBITROS:}

1. Andrés Felipe Botía Osorio, Tarjeta Profesional No. 201216818

2. María Camila Carreño, Tarjeta Profesional No. 201126318

3. Ana María Valderrama, Tarjeta Profesional No. 201215291

\section{D.- DEMANDA}

\section{Pretensiones de la demanda:}

Amanda de Puentes, a través de sus apoderados solicitó al Tribunal despachar favorablemente las siguientes pretensiones, contenidas en el escrito de la demanda: 
Que se le declare civilmente responsable a PC por los perjuicios ocasionados, lo cuales divide en dos, según su modalidad de responsabilidad. De esta manera, en cuanto a la responsabilidad contractual que le adjudica a la parte demandada, sus pretensiones consisten en:

- El pago de los perjuicios derivados a causa del incumplimiento contractual respecto la fecha de entrega de la obra, siendo estos perjuicios correspondientes al lucro cesante, refiriéndose éstos a las "ganancias no percibidas durante la época más importante del año" y al daño emergente, fruto del sobrecosto de un $20 \%$ de la obra, el cual alegan fue asumido por ellos.

- Ruptura del tubo

En cuanto a la responsabilidad extracontractual alegan que la muerte del señor Armando ocasiono los siguientes perjuicios:

- La indemnización por el robo de los computadores por parte de uno de los empleados de PC.

- Daños morales sufridos por la esposa y los dos hijos menores del occiso, refiriéndose estos a los subjetivos y a la vida en relación.

- Daños patrimoniales, correspondientes al daño emergente, derivado de los costos funerarios y médicos, y al lucro cesante, en razón de la falta de apoyo económico.
Contestación a la demanda, a través de los apoderados de Juan Cuadrado, gerente de PC:

- Los sobrecostos respectivos al retraso en la fecha de entrega de la construcción fueron asumidos por el contratista.

- No hay certeza sobre las ganancias que se dejaron de percibir por el incumplimiento del contrato.

- El robo de los computadores fue cometido por un trabajador que se encontraba por fuera de sus funciones.

- La demandante no tiene legitimación por activa con respecto al daño ocasionado al inmueble vecino por el rompimiento de un tubo en la otra.

- inexistencia del nexo causal entre alguna conducta del demandado y los daños acaecidos por la muerte de Juan Cuadrado, en la medida en que el accidente ocurrió como resultado de la culpa exclusiva de la víctima y de una causa extraña, razón por la cual no se configura la responsabilidad, y por lo tanto, no hay lugar a las pretensiones sobre perjuicios patrimoniales y extrapatrimoniales.

\section{La excepción planteada por la demandada}

En este punto el Tribunal abordará el estudio de la excepción planteada por la parte demandada en cuanto a la falta de legitimación por activa de Mónica. Así: concordamos con que Mónica no es parte demandante en este asunto, no suscribió el contrato objeto de la Litis, ni firmo el convenio arbitral que fundamenta la competencia 
de este proceso; contra ella no pretenden nada los demandantes y por ello no debe ser vinculada a este proceso.

En virtud de lo anterior, entra el Tribunal a estudiar la demanda y resolver los problemas jurídicos planteados en el Acta de Misión radicada el 29 de agosto de 2013.

\section{En lo referente al daño emergente}

En primer lugar, el Tribunal se referirá al relamo de la parte demandante respecto de la indemnización por el perjuicio ocasionado en el patrimonio de Armando a raíz de los sobrecostos del $20 \%$ que, dicen, se generaron como consecuencia del incumplimiento en la fecha de entrega de la obra. De acuerdo con la accionante, estos sobrecostos fueron asumidos por el occiso, lo que derivó en un daño emergente. No obstante, la parte demandada alega que el daño reclamado es inexistente, pues quien asumió el valor de los sobrecostos fue PC, quien, de acuerdo con los representantes de ésta, nunca cobraron a los contratantes los $\$ 30.000 .000$.00 correspondientes al $20 \%$ de sobrecostos.

De acuerdo con el artículo 1614 del Código Civil, el daño emergente consiste en "la pérdida que proviene de no haberse cumplido la obligación o de haberse cumplido imperfectamente, o de haberse retardado su cumplimiento (...)" En este sentido, en el caso que nos concierne, es claro que hubo un retardo en el cumplimiento de la obligación, y que como bien lo presupuesto Juan Cuadrado, representante de PC, este retraso implicó en gran medida que la obra costara 20\% más de lo previsto. Sin embargo, no se presenta con la misma claridad el daño alegado por la parte demandante, pues como lo establece el Consejo de Estado en su providencia de 4 de diciembre de 2006, el daño emergente "conlleva que algún bien económico salió o saldrá del patrimonio de la víctima"”v , y en el caso no se evidencia dicha pérdida económica en el patrimonio del occiso. Encuentra el Tribunal que en el acervo probatorio no se halla ninguna prueba que evidencie que fue la parte demandada quien asumió los sobrecostos, pues, por el contrario, resulta indiscutible que, de acuerdo a lo pactado en el contrato, lo que se pagó correspondía al anticipo del 30\% que se pagaría a la firma del contrato, quedando un saldo correspondiente al 70\%, el cual sería pagado cuando fuese entregada la obra. Nunca se menciona ningún otro tipo de pago, distinto al anticipo ya mencionado. Por lo tanto, es evidente, que Armando solo corrió con los gastos del anticipo y no se le llegó a cobrar en ningún momento el $20 \%$ del precio global del contrato correspondiente a los sobrecostos.

Por lo anterior, desestima el Tribunal la pretensión de la parte demandante en relación al perjuicio por daño emergente exigido.

\section{En lo referente al lucro cesante}

En materia de responsabilidad civil contractual una vez se tienen probados los elementos que la constituyen, a saber, la existencia de un con-

IV Consejo de Estado, Sala de lo Contencioso Administrativo, Sección tercera, sentencia de 4 de diciembre de 2006. Magistrado ponente: Mauricio Fajardo Gómez. 
trato válidamente celebrado, el incumplimiento de una o más obligaciones contractuales imputables por dolo o culpa al deudor, un daño o perjuicio y un nexo causal, puede hablarse del surgimiento de la obligación de indemnización de perjuicios, ya sea por daño emergente o lucro cesante. (Artículos 1613 y 1614 de Código Civil)

De los anteriores elementos entraremos a estudiar el daño, ya que éste es objeto de controversia en el presente caso. En este orden de ideas, se procederá a determinar si existe un daño y si éste constituye un perjuicio indemnizable.

Según la doctrina, para que un daño sea indemnizable debe ser personal y cierto. La certeza implica que solo será indemnizable el daño virtual, es decir aquel que "en el curso normal de los acontecimientos muy seguramente se producirá" ${ }^{\prime}$ y no el daño eventual, es decir en el que la víctima "solo tenía expectativas muy remotas de obtener un beneficio, del que se dice despojado"VI. Así pues, en este caso, alegan los demandantes que en razón de un daño cierto ocasionado por el incumplimiento contractual de $\mathrm{PC}$, debe reconocerse el lucro cesante, a causa del patrimonio que dejo de percibirse dentro de los meses que comprenden las vacaciones de mitad de año. Por su parte, los demandados alegan que no hay lugar a indemnización de perjuicios a título de lucro cesante en tanto no hay certeza de los ingresos que dejaron de percibir Armando y Ana. Lo anterior, en vista de que no

$\checkmark \quad$ TAMAYO, Javier. La pérdida de una oportunidad. En: De la responsabilidad civil. Tomo IV. Bogotá: Editorial Temis. 1999. P. 19.

VI Ibídem. P. 19. Expresión tomada de los hechos relevantes del caso. es posible probar una base de ingresos del local o sede que estaba siendo remodelada, pues esta figuraba como una nueva sucursal. Según alegan, lo anterior implica que no se trata de un perjuicio consolidado, sino de un perjuicio futuro, no consolidado a partir de una situación inexistente, por lo cual no existe certeza del daño y por ende las ganancias no-percibidas configuran un daño emergente de "pérdida de oportunidad".

En cuanto a lo anterior, considera este Tribunal que aunque se trataba de una nueva sucursal, la actividad productiva que se iba a desarrollar era la misma a la que se dedicaban Armando Puentes y su esposa Ana desde tiempo atrás, y que según los hechos del caso constituía "un negocio muy próspero"vII. Así, dicha actividad constituía una actividad productiva para los demandantes, de la cual devengaban ciertos ingresos como se infiere del acervo probatorio. Considerando lo anterior, es muy probable que en el curso normal de los hechos, de no haberse incumplido el contrato, los demandantes hubiesen percibido algún lucro derivado de la actividad durante la época vacacional, así correspondiese al monto que normalmente ganarían, en cualquier momento del año, como empresa dedicada a la industria del turismo.

Aquí es importante distinguir entre los ingresos que normalmente ganan como empresa dedicada a la industria del turismo, y los ingresos "adicionales" que se podría esperar de la mejor y más rentable época del año, considerando que

VII Expresión tomada de los hechos relevantes del caso. 
ante la primera categoría nos encontramos con un lucro cesante mientras que frente a la otra hablamos de una perdida de oportunidad. En el primer caso hay lugar a lucro cesante teniendo en cuenta que como lo prevé el artículo 1614 del Código Civil, hubo una ganancia o provecho que dejo de reportarse para Armando Puentes y su cónyuge, a consecuencia de haberse retardado el cumplimiento de la obligación. Ahora bien, aunque como lo alegan los demandados "no se puede tomar en cuenta un ingreso fijo o base salarial al momento de acaecer el hecho culposo causante del perjuicio", la Corte Suprema de Justicia en Sala de Casación Civil, ha mencionado que "no obstante, la deficiencia probatoria respecto a la cuantía del lucro cesante no impide su tasación" vilI.

“En ese orden de ideas (...) ante las deficiencias probatorias para cuantificar un lucro cesante efectivamente causado (pasado) o con un alto grado de posibilidad de producirse (futuro), debe echar mano de los métodos de evaIuación que permitan determinarlo, ya sea por analogía o comparación, o por proyección o modelización."

Así pues, el hecho de que de una actividad no se perciba un ingreso fijo o no se tenga una base salarial, no es motivo para descartar la indemnización de perjuicios por lucro cesante siempre que existan otros medios para tazar el perjuicio.

VIII Corte Suprema de Justicia, Sala de Casación Civil, sentencia 20 de enero de 2009. Magistrado ponente: Pedro Octavio Munar Cadena.

IX

GONZÁLEZ, Álvaro Andrés. El daño o perjuicio. En: El derecho de las obligaciones. Tomo II. Bogotá: Universidad de los Andes. 2010.
Por otra parte, el presente Tribunal considera pertinente aclarar que en este caso no puede hablarse de un perjuicio no consolidado a partir de una situación inexistente, sino de un perjuicio consolidado. Lo anterior teniendo en cuenta que "el perjuicio presente o consolidado oscila entre dos extremos temporales: el instante en que ocurrió el daño o el hecho dañoso y el momento en que el juez valora la existencia, contenido y prolongación del perjuicio. En cambio el perjuicio futuro o no consolidado se encuentra fuera de dicho intervalo."x

En este caso, los demandantes alegan los daños ocasionados en las vacaciones de mitad de año del año pasado, hecho que se sitúa dentro de los dos extremos temporales previamente citados, razón por la cual no alegan un daño futuro, sino un daño que ocurrió entre el incumplimiento del contrato (marzo del año pasado) y el pronunciamiento del presente tribunal de arbitramento. Es decir que se trata de un daño consolidado. Lo anterior implica que de existir el perjuicio este ya es cierto y por ende, tratándose del lucro cesante, se concluye la falta del ingreso"XII

Por último, considera la corte que los ingresos "adicionales" que se podrían esperar de la mejor y más rentable época del año, constituyen una pérdida de oportunidad en tanto "la victima está en una situación en la que el hecho del agente le impide tener la posibilidad de que el

X Consejo de Estado, Sección tercera. Auto del 3 de marzo de 2010. Radicación numero: 25000-23-26-000-2006-02068-01(37763). Consejero ponente: Mauricio Fajardo Gómez.

XI

TAMAYO, Javier. Ob. cit. P. 34. 
azar le otorgue un beneficio o le evite un daño" así " la posibilidad existe y ya no es cuestión del paso del tiempo o de confluencia de otros factores, sino que solo falta que intervenga la causa esperada que desatara la expectativa"xil. En este caso, se trata de una perdida de oportunidad, en tanto no se tenía certeza de dichos beneficios. No obstante lo anterior solo tiene fines aclarativos considerando que este tribunal no está facultado para pronunciarse sobre pretensiones que no fueron formuladas por el demandante.

\section{De la responsabilidad de la persona jurídica.}

Ahora se dispone el Tribunal a referirse respecto al hurto de los computadores y demás elementos de la oficina de Armando por parte de uno de los empleados de PC.

El régimen de responsabilidad civil establecido en el Código Civil no hace referencia explícita de las personas jurídicas, limitándose solo al uso del término "personas". Sin embargo, la jurisprudencia de la Corte Suprema de Justica ha establecido que no se debe creer que "de la responsabilidad extracontractual están excluidas las personas morales, o más concretamente, las personas jurídicas (...)"XIII. Si bien estas no deben responder penalmente, este no es el caso en materia civil, pues “a diferencia de la condenación penal, la condenación civil no es un castigo; tiende solamente a reparar el daño.

XII Ibídem.

XIII Corte Suprema de Justicia, Sala de Casación Civil, sentencia 12 de mayo de 1939. Magistrado ponente: Arturo Tapias.
Ahora si la persona moral no puede ser castigada, en cambio tiene tanta capacidad como la persona física de resarcir los perjuicios que infiera a terceros"xiv. Resulta entonces evidente que aunque la Ley no establezca de manera explícita a responsabilidad civil de las personas jurídicas, éstas están cobijadas bajo este régimen, quedando claro, que una persona jurídica también puede ser responsable civilmente $\mathrm{y}$, por lo tanto, debe responder por los daños que irrogue a terceros.

En este sentido, la parte demandante, exige dentro de sus pretensiones que se le indemnice por el robo de los computadores por parte de un empleado de PC. De esta manera, en sus alegatos de conclusión, afirma que bajo la figura de responsabilidad directa, estando ésta consagrada en el artículo 2341 del Código Civil, se debe declarar responsable a PC por el precio de los computadores y elementos de la oficina de propiedad de Armando, que fueron hurtados por el joven empleado de la misma. Y aclaran que si bien "el hecho no se generó en horas laborales, si dicho empleado tenía la posibilidad de encontrarse en el lugar de construcción de la obra, es porque podía ingresar a este lugar en representación de $P C$, para desarrollar las funciones que se le había encargado"xv, lo cual, de acuerdo con la parte demandante, implica que PC debe responder por dicho acto como si fuese propio.

En materia de la responsabilidad civil de las personas jurídicas, la jurisprudencia ha ido evo-

XIV Ibídem.

XV Alegato de conclusión de la parte demandante. 
lucionando, destacándose tres periodos ${ }^{\mathrm{XV}}$. Así en primer lugar, se reconocía la culpa de las personas jurídicas fundada en los conceptos de "in eligendo" e "in vigilando" (la mala elección y la falta de vigilancia del empresario). Luego, se desplazó esta concepción para dar lugar a la responsabilidad indirecta, la cual comprendía la "teoría organicista", y las "fallas del servicio". Finalmente, como lo establece la Corte Suprema de Justicia en su providencia de 28 de octubre de 1975, se adoptó una responsabilidad "directa y no directa, por la conducta de sus agentes, causantes de daños a terceros, cualquiera que sea la posición jerárquica de aquellos dentro de la entidad jurídica"XvII. Dice la Corte en esta misma sentencia que la responsabilidad no es indirecta en tanto los agentes no están "bajo la 'dependencia', ni tampoco al 'cuidado' de la entidad moral" como si se hallan el hijo, el pupilo o el alumno. Así, la CSJ termina por establecer que el acto realizado por algún agente de la persona jurídica que se encuentre bajo su subordinación y en ejercicio de sus funciones conlleva a la responsabilidad directa de ésta.

En cuanto al caso materia de discusión, la parte demandada reitera lo estipulado por la jurisprudencia en cuanto a la responsabilidad directa de las personas jurídicas, en tanto se entiende que los actos de los agentes que se encuentran bajo su subordinación son considerados como actos propios de éstas. Sin embargo, sostienen los representantes del demandado que Francisco, el

XVI Corte Suprema de Justicia, Sala de Casación Civil, sentencia 20 de abril de 1993. Magistrado ponente: Alberto Ospina Botero.

XVII Ibídem. agente responsable del daño, no se encontraba en el ejercicio de sus funciones laborales al momento de hurtar los computadores, "ni tampoco tramitaba un interés particular de la persona moral" $X^{\mathrm{VIII}}$, motivo por el cual no hay razón para "asumir que el hecho dañoso corresponde a una actuación de la persona jurídica, por lo que ésta no puede ser declarada responsable"xix.

Frente a este aspecto, encuentra el Tribunal que, con base en la jurisprudencia ya presentada, es válido el argumento de la parte demandada, pues como se expuso anteriormente, es requisito para que se configure la responsabilidad directa de la persona jurídica, que su agente haya actuado el ejercicio de sus funciones, cosa que no sucede en el presente caso, ya que, aunque la demandante alega que la presencia del señor Francisco en la obra implica que podía ingresar allí en representación de PC, considera el Tribunal que este argumento no se encuentra fundamentado para alegar que el agente se encontraba desarrollando funciones laborales, y mucho menos que el hurto se haya desprendido de la relación de subordinación del señor Francisco con PC. Por consiguiente, no se presentaron los requisitos exigidos para dar lugar a la responsabilidad civil extracontractual directa de PC.

En virtud de lo anterior, desestima el Tribunal la pretensión de la parte demandante en relación a la indemnización por el costo de los elementos robados por el señor Francisco.

XVIII Alegato de conclusión de la parte demandada

XIX Ibídem 


\section{De la causalidad en actividades peligrosas}

Finalmente, procede el Tribunal a estudiar la causa extraña alegada por la parte demandada para exonerarse de la responsabilidad extracontractual derivada de la muerte de Armando Puentes.

En la responsabilidad civil deben establecerse dos nexos causales: entre la culpa y el hecho, de lo contrario se configuraría causa extraña; y entre el hecho y el daño, si no el daño sería indirecto $^{\mathrm{xx}}$. En este sentido, es menester estudiar si efectivamente en el caso concreto se puede establecer un nexo causal entre la culpa del agresor (PC) y los daños sufridos por los demandantes, teniendo en cuenta la actividad peligrosa que se realizaba y las implicaciones de los hechos acaecidos, como lo son el terremoto y la calidad del muro que le causó la muerte al Sr. Armando Puentes.

En primer lugar, es necesario referirse a la responsabilidad por actividades peligrosas. Esta modalidad está regulada en el artículo 2356 de C.C., el cual ha sido desarrollado reiteradamente por la Sala de Casación Civil de la Corte Suprema de Justicia, según la cual todas las actividades lícitas, que generan un riesgo especial y que ponen en situación de indefensión a los terceros que se puedan ver afectados, son catalogadas como actividades peligrosas ${ }^{\mathrm{Xx}}$. Entre

XX ORTIZ, Gerardo. EI nexo causal en la responsabilidad civil. En: EI derecho de las obligaciones. Tomo II. Bogotá: Universidad de los Andes. 2010. P. 315.

XXI CASTRO DE CIFUENTES, Marcela. La responsabilidad civil objetiva: componente indispensable para la modernización del derecho de daños. En: Realidades y tendencias del derecho en el siglo XXI. Tomo IV: Derecho Privado. Bogotá: Editorial Temis, 2010. P. 19. estas actividades peligrosas se encuentran las obras de construcción, las cuales implican un riesgo inminente para terceros no interesados. Considerando lo anterior, puede decirse que las actividades de construcción realizadas por PC para remodelar la sede de "Nadie te quita lo viajado", deben ser estudiadas a la luz de la regulación de las actividades peligrosas.

Así, la CSJ ha desarrollado una extensa línea jurisprudencial referente al tema, que ha puesto en evidencia el interés de proteger a las posibles víctimas de las actividades peligrosas. En esta medida, la Corte estableció la presunción de la culpa del guardián de la actividad, es decir, quien tiene el control, manejo y un poder efectivo de dirección, sobre la actividad en el momento de su ejecución ${ }^{x \times 1 I}$. Esta presunción solamente podrá ser desvirtuada en la medida en que se compruebe la existencia de causa extraña o de culpa exclusiva de la víctima, lo que desligaría el vínculo entre la culpa y el hechoxill.

Ahora bien, es pertinente estudiar el vínculo causal en la situación fáctica para determinar si este efectivamente existe o si puede ser desvirtuado como pretenden los abogados de PC. Así, se pueden establecer tres hechos fundamentales a través de los alegatos de las partes y del acervo probatorio: la imprudencia del occiso al entrar a la obra desatendiendo las indicaciones de la constructora, el terremoto de 4.0 grados en la escala de Richter y la falta de calidad en

XXII Corte Suprema de Justicia, Sentencia 13 de mayo de 2008. Magistrado ponente: César Julio Valencia Copete.

XXIII Corte Suprema de Justicia, Sentencia de 26 de agosto de 2010. Magistrado ponente: Ruth Marina Díaz Rueda. 
los materiales con los que se construía el muro.

En primer lugar, si bien la constructora había establecido unas precauciones que el Sr. Puentes no acató, no es posible determinar la culpa exclusiva de la víctima. No se puede establecer que "el hecho de la víctima es aquel sin el cual no se habría producido el perjuicio"xxıv, ya que, PC al dedicarse al negocio de la construcción no pueden limitarse a realizar una simple advertencia, sino que su diligencia debe ir mucho más allá y tomar las precauciones suficientes. Ellos, sabiendo cuál es su industria deben contar con la pericia suficiente para conocer los riesgos de su actividad, en tanto es una actividad peligrosa, de ahí que tengan que tomar precauciones específicas de esa industria.

En segundo lugar, si bien es cierto que antes de que cayera el muro aconteció un terremoto de 4.0 grados en la escala de Richter, esta tampoco es la causa necesaria ni suficiente del daño. Los expertos del Ingeominas ${ }^{x x v}$ han podido determinar que este grado de terremoto no representa daños a las edificaciones ${ }^{x x v 1}$. Así pues, un terremoto efectivamente es irresistible e imprevisible por lo que se puede categorizar dentro de los posibles causantes de fuerza mayor en los términos del artículo 84 del Código civil; sin embargo, en el caso concreto la magnitud del terremoto

XXIV Corte Suprema de Justicia, Sentencia 27 de febrero de 1998. Magistrado ponente: Rafael Romero Sierra.

XXV Instituto encargado, entre otras cosas, de adelantar el seguimiento y monitoreo de amenazas de origen geológico.

XXVI Seminario Sismotectónica de Colombia (1995, mar. 23: Santafé de Bogotá). Bogotá: Ingeominas: Sociedad Colombiana de Geotecnia, 1995. 01/01/1995 no es suficiente para que un muro se derrumbara por lo que es posible concluir que la causa del derrumbamiento del mismo está relacionada con los materiales y la técnica empleados para su construcción. Al respecto la CSJ en sentencia del día 27 de febrero de 2009 se refiere diciendo que si bien al examinar un posible caso fortuito o fuerza mayor es necesario estudiar el caso en concreto "ello no obsta para que puedan trazarse ciertas directrices que, por su fuerza intrínseca, a la par que jurídica, permitan singularizar $y$, por ende, dotar de fisonomía al fenómeno en cuestión, el cual, por vía de ejemplo, no puede concurrir con la culpa del demandado que haya tenido un rol preponderante en la acusación del daño (...) ni puede estar 'ligado al agente, a su persona ni a su industria' (...) habida cuenta que debe tratarse, según doctrina citada en este último fallo, de 'un acontecimiento extraordinario que se desata desde el exterior sobre la industria, acontecimiento imprevisible y que no hubiera sido posible evitar aun aplicando la mayor diligencia sin poner en peligro toda la industria y la marcha económica de la empresa y que el industrial no tenía por qué tener en cuenta ni tomar en consideración"xxvı"(Negrilla fuera del texto).

En este sentido, si bien la fuerza mayor es irresistible, sí puede preverse que en cualquier momento puede ocurrir, y por eso las personas dedicadas a esta industria deben tomar precauciones como construir con materiales de buena calidad que le den a la estructura buenos cimientos y con esto evitar y con esto evitar futu-

XXVII Corte Suprema de Justicia, Sentencia 27 de febrero de 2009. Magistrado ponente: Arturo Solarte Rodríguez. 
ros daños. La falta de diligencia que se da como fruto de la negligencia de construir con materiales inadecuados es la conducta que vincula el daño sufrido por la víctima con la culpa del agresor, en este caso PC, ya que, existe culpa cuando el agresor no prevé las consecuencias nocivas de su conducta habiendo debido preverlas o cuando habiéndolas previsto confía imprudentemente en lograr evitarlas ${ }^{\mathrm{Xx}}{ }^{\prime \prime I}$.

Ahora bien, la CSJ, a través de la sentencia del 9 de febrero de 1976, estudió las implicaciones del artículo 2357 (La apreciación del daño está sujeta a reducción, si el que lo ha sufrido se expuso a él imprudentemente) y ha podido establecer que sólo cuando el perjuicio se genera por culpa exclusiva de la víctima, es decir, cuando el demandado no contribuyó de ninguna manera a su producción sí puede este quedar exento de la obligación de indemnizar. Por lo cual, en la medida en que hay causas concurrentes como lo son la imprudencia de la víctima y la falta de diligencia en la construcción del muro, es necesario graduar la culpa.

Siendo así, este tribunal condena a PC a indemnizar el $40 \%$ de los perjuicios que sufrieron los demandantes.

Considerando la culpa de los demandados y que la causa adecuada fue la negligencia de PC, se ordena a que se pague los perjuicios patrimoniales y extrapatrimoniales ocasionados por responsabilidad civil extracontractual a Ana de

XXVIII CASTRO, Marcela. El hecho ilícito. Nociones fundamentales. En: El derecho de las obligaciones Tomo II. Bogotá: Universidad de los Andes. 2010. P. 22. puentes y sus dos hijos, a título de lucro cesante

y daño emergente por la muerte de su cónyuge y padre.

En virtud de todo lo expuesto, El Tribunal de Arbitramento instaurado por ANA DE PUENTES contra JUAN CUADRADO GERENTE DE PROFESIONALES EN CONSTRUCCIÓN S.AS., en nombre de la República de Colombia y por autoridad de la Ley,

\section{RESUELVE}

PRIMERO: DENEGAR la pretensión de la demanda en relación al perjuicio por daño emergente por los sobrecostos de la obra.

SEGUNDO: DENEGAR la pretensión de la demanda en relación a la indemnización por el costo de los elementos robados por el señor Francisco.

TERCERO: Que se CONDENE a PC a indemnizar a Ana de Puentes por el lucro cesante de la epoca “más importante del año" por responsabilidad civil contractual

CUARTO: Que se CONDENE a PC a indemnizar el $40 \%$ de los perjuicios que sufrieron los demandantes, por perjuicios patrimoniales y extrapatrimoniales ocasionados por responsabilidad civil extracontractual a Ana de puentes y sus dos hijos, a título de lucro cesante y daño emergente por la muerte de su cónyuge y padre.

LOS ÁRBITROS,

\section{ANDRÉS FELIPE BOTÍA} MARÍA CAMILA CARREÑO ANA MARÍA VALDERRAMA 
ANEXO 13: AUTO DE GRADUACIÓN DE CRÉDITOS

AUTO

SUPERINTENDENCIA DE SOCIEDADES

Bogotá D. C.,

PROCESO: CREACIONES MODERNAS S. A.

APERTURA: AUTO 1

LIQUIDADOR: DANIEL PINZÓN Y FEDERICO LEWIN

REFERENCIA: CALIFICACION Y GRADUACION DE CREDITOS

\section{ANTECEDENTES}

\section{ETAPA ACUERDO DE REESTRUCTURACIÓN}

Ante la situación de cesación de pagos a sus acreedores, por parte de Creaciones Modernas Ltda., la misma empresa solicitó iniciar un proceso de reorganización ante la Superintendencia de Sociedades. En el marco de este proceso se citaron a los acreedores para acordar la reorganización de la empresa.

\section{ETAPA DE LIQUIDACIÓN OBLIGATORIA}

Al no haberse podido llegar a un acuerdo de reorganización de la empresa, y siguiendo el artículo 47 de la Ley 1116 de 2006, la Superintendencia de Sociedades, mediante auto 025785 , abrió el proceso de liquidación obligatoria de los bienes que conforman el patrimonio de Crea- ciones Modernas S. A. En este mismo auto se designaron como liquidadores a Daniel Pinzón y Federico Lewin, quienes tomaron posesión de su cargo el 15 de septiembre de 2011.

Acudieron los siguientes acreedores a la presentación de sus respectivos créditos, en la reunión llevada a cabo el día 23 de septiembre de 2011:

1. BANCO DEL COMERCIANTE: a través de sus apoderados, María Alejandra Cardona Camacho y María Alejandra Guerrero Caballero, se presentaron como prueba del crédito un contrato de hipoteca por la suma de 120 millones de pesos.

2. TRABAJADORES: sus apoderados, Juan Pablo Guzmán, Andrés F. Hernández y Nicolás Mazuera, presentaron como pruebas de los créditos los contratos de trabajo y las liquidaciones de los respectivos contratos de trabajo. Estos créditos se dividen en:

\subsection{0 millones por salarios no pagados.}

2.225 millones por deudas en aportes al Seguro Social.

2.380 millones por indemnizaciones a los trabajadores despedidos sin justa causa.

3. SEGUROS UNIVERSAL: Sus apoderados, María Paula Macías y Alejandro Torres Cortés, presentaron como prueba del crédito el contrato de seguro por en el cual se estipula el monto de la prima, que es de 80 millones de pesos.

4. BANCO DEL EMPRESARIO: Juan Pablo Amaya, Daniel Carrillo y Andrea Ramírez, en calidad 
de apoderados de este banco, presentaron el contrato de mutuo suscrito por Creaciones Modernas Ltda. con el Banco del Empresario así como su respectivo pagaré, la constitución de la hipoteca de la planta industrial de Creaciones Modernas a favor del Banco, el certificado de registro de hipoteca en la oficina de registro de instrumentos públicos y la copia del cheque por medio del cual el Banco del Empresario desembolsó 700 millones a Creaciones Modernas.

\section{ACREEDORES FISCALES}

5.1 DIAN: sus apoderados, Andrés Caro y Martha Vives, presentaron los estados de cuenta y las declaraciones de renta de la compañía, en virtud de los cuales se prueba la deuda de 280 millones a favor de la DIAN.

\subsection{SECRETARÍA DISTRITAL DE HACIENDA DE} BOGOTÁ: sus apoderados, Andrés Caro y Martha Vives, presentaron los estados de cuenta y las declaraciones de renta de la compañía, en virtud de los cuales se prueba la deuda de 20 millones de pesos a favor de esta secretaría distrital.

\section{EMPRESAS PRESTADORES DE SERVICIOS PÚ-} BLICOS: como apoderados de CONDENSA S. A., LA EMPRESA DE ACUEDUCTO Y ALCANTARILLADO DE BOGOTÁ y TELMEX, Guillermo Andrés Alaix Cardona y Luis Alberto Rojas presentaron como prueba de los créditos los contratos celebrados entre Creaciones Modernas Ltda. con cada una de estas empresas, los respectivos requerimientos en mora y sus correspondientes facturas de cobro. De esta manera se acreditan las deudas que, juntas, suman un total de 300 millones de pesos.

7. BANCO SOLIDARIO: sus representantes en este proceso solicitaron el reconocimiento de la deuda por 60 millones a favor del banco. Como prueba del crédito presentaron el contrato de prenda sin tenencia entre las dos partes y los estados de cuenta que certifican el monto de la deuda.

8. PERSONAS NATURALES: los apoderados de Ios señores Armando Casas, Dolores de Barriga, Carlos Cepeda y Antonio Nariño presentaron los contratos de mutuo en los cuales se certifican los créditos por 25 millones, 15 millones, $10 \mathrm{mi}$ llones y 150 millones a favor de cada una de estas personas, respectivamente.

9. PROVEEDORES: María Jimena Rojas y Juan Pablo Vargas, como apoderados de Textiles JJ S. A. y Formidex Ltda., presentaron los créditos que sumados ascienden al monto de 800 millones, divididos en una deuda por 500 millones a favor de Textiles JJ S. A. y 300 millones a favor de Formidex Ltda. Como prueba de estos créditos fueron presentadas las facturas que comprueban la obligación original y el cumplimiento reiterado entre las partes, las facturas que acreditan la cesación de pago y la existencia del crédito, los registros de matrícula mercantil de las sociedades acreedoras y los estados financieros de estas sociedades.

10. LEASING EMPRESARIAL S. A.: sus representantes presentaron como pruebas el contrato de leasing financiero y su respectivo pagaré en 
blanco con carta de instrucciones, y el estado de cuenta que acredita que la deuda es de un monto de 400 millones.

\section{CALIFICACIÓN Y GRADUACIÓN DE CRÉDITOS}

Antes de calificar y graduar los créditos presentados, el Despacho procede a presentar la relación de activos' y pasivos de la sociedad en liquidación a la fecha para así luego determinar los montos correspondientes a los diferentes acreedores.

\subsection{PATRIMONIO}

\section{ACTIVOS}

\section{Corrientes}

Caja y Bancos: $\$ 1.500 .000$

Cuentas por cobrar: $\$ 15.000 .000$

Fijos

Inmbuebles: \$1.000.000.000

Muebles: $\$ 80.000 .000$

Materias primas y productos: $\$ 150.000 .000$

TOTAL ACTIVOS: $\$ 1.246 .500 .000$

\section{PASIVOS}

\section{$\underline{\text { Corrientes }}$}

Obligaciones financieras

Banco del Empresario: $\$ 700.000 .000$

La maquinaria no hace parte de la propiedad de la sociedad, ya que pertenece a la empresa Leasing Empresarial S. A.
Banco Solidario: $\$ 60.000 .000$

Banco del Comerciante: $\$ 120.000 .000$

Proveedores de materias primas: $\$ 800.000 .000$

Particulares: $\$ 200.000 .000$

Obligaciones laborales

Salarios: $\$ 250.000 .000$

Aportes S. S: $\$ 25.000 .000$

Indemnizaciones: $\$ 80.000 .000$

Gastos por pagar

Leasing Empresarial: \$400.000.000

Servicios públicos: $\$ 300.000 .000$

Seguros Universal: 80.000 .000

Impuestos

Renta: $\$ 280.000 .000$

Predial: $\$ 20.000 .000$

TOTAL PASIVOS: $\$ 3.315 .000 .000$ 


\subsection{CALIFICACIÓN Y GRADUACIÓN DE CRÉDITOS}

PRIMERA CLASE. De acuerdo con los artículos 2495 y 2496 del Código civil pertenecen a esta categoría los siguientes créditos:

\begin{tabular}{|c|c|c|c|c|}
\hline No. & ACREEDOR & $\begin{array}{l}\text { APODERADO O } \\
\text { REPRESENTANTE }\end{array}$ & $\begin{array}{l}\text { CUANTÍA } \\
\text { SOLICITADA }\end{array}$ & MONTO A PAGAR \\
\hline & CRÉDITOS LABORALES & & & \\
\hline 2.1 & Salarios no pagados & $\begin{array}{l}\text { JUAN PABLO GUZMÁN } \\
\text { ANDRÉS F. HERNÁNDEZ } \\
\text { NICOLÁS MAZUERA } \\
\end{array}$ & 250.000 .000 & \\
\hline 2.2 & Deudas en aportes al Seguro Social & $\begin{array}{l}\text { JUAN PABLO GUZMÁN } \\
\text { ANDRÉS F. HERNÁNDEZ } \\
\text { NICOLÁS MAZUERA }\end{array}$ & 25.000 .000 & \\
\hline 2.3 & $\begin{array}{l}\text { Indemnizaciones a los trabajadores } \\
\text { despedidos sin justa causa }\end{array}$ & $\begin{array}{l}\text { JUAN PABLO GUZMÁN } \\
\text { ANDRÉS F. HERNÁNDEZ } \\
\text { NICOLÁS MAZUERA } \\
\end{array}$ & 80.000 .000 & \\
\hline & Subtotal créditos laborales & & & 355.000 .000 \\
\hline & Fiscales & & & \\
\hline 5.1 & DIAN & \begin{tabular}{|l} 
ANDRÉS CARO Y MARTHA \\
VIVES
\end{tabular} & 280.000 .000 & 280.000 .000 \\
\hline 5.2 & $\begin{array}{l}\text { SECRETARÍA DISTRIAL DE HACIENDA DE } \\
\text { BOGOTÁ }\end{array}$ & $\begin{array}{l}\text { ANDRÉS CARO Y MARTHA } \\
\text { VIVES }\end{array}$ & 20.000 .000 & 20.000 .000 \\
\hline & Subtotal fiscales & & & 300.000 .000 \\
\hline & Total créditos primera clase & & & 655.000 .000 \\
\hline
\end{tabular}

De los $\$ 591.500 .000$ restantes para cubrir con los créditos de segunda y tercera clase, teniendo en cuenta que ninguno de ellos tiene prelación sobre el otro y que deben ser indemnizados de manera proporcional. Al comparar el monto de $\$ 60.000 .000$ del crédito de segunda clase con el crédito de $\$ 700.000 .000$ de tercera clase, se llega a la conclusión que de los
$\$ 591.500 .000$ del saldo, para que su distribución sea proporcional, el $92.105 \%$ de esta cifra corresponde al pago de la deuda con el Banco del Empresario y el restante $7.895 \%$ le corresponde al Banco Solidario. Por esta razón, se le reconoce al Banco del Empresario el pago de $\$ 544.801 .075$ pesos y al Banco Solidario la suma de $\$ 46.698 .925$. 


\section{SEGUNDA CLASE}

De acuerdo con el artículo 2497 del Código civil pertenecen a esta categoría los siguientes créditos:

\begin{tabular}{|l|l|l|l|l|}
\hline No. & \multicolumn{1}{|c|}{ ACREEDOR } & \multicolumn{1}{|c|}{$\begin{array}{c}\text { APODERADO O } \\
\text { REPRESENTANTE }\end{array}$} & $\begin{array}{c}\text { CUANTÍA } \\
\text { SOLICITADA }\end{array}$ & $\begin{array}{c}\text { MONTO A } \\
\text { PAGAR }\end{array}$ \\
\hline & PRENDA & & & \\
\hline 7 & BANCO SOLIDARIO & $\begin{array}{l}\text { ANDRÉS BARRERA } \\
\text { CARLOS SILVA } \\
\text { LUISA SAMUDIO }\end{array}$ & 60.000 .000 & 46.698 .925 \\
\hline & Total créditos segunda clase & & 60.000 .000 & 46.698 .925 \\
\hline
\end{tabular}

\section{TERCERA CLASE}

De acuerdo con el artículo 2499 del Código civil pertenecen a esta categoría los siguientes créditos:

\begin{tabular}{|l|l|l|l|l|}
\hline No. & \multicolumn{1}{|c|}{ ACREEDOR } & APODERADO O REPRESENTANTE & \multicolumn{1}{c|}{$\begin{array}{c}\text { CUANTÍA } \\
\text { SOLICITADA }\end{array}$} & $\begin{array}{c}\text { MONTO A } \\
\text { PAGAR }\end{array}$ \\
\hline & HIPOTECA & & & \\
\hline 4 & BANCO DEL EMPRESARIO & $\begin{array}{l}\text { ANDREA RAMÍREZ } \\
\text { JUAN PABLO AMAYA } \\
\text { DANIEL CARRILLO }\end{array}$ & 700.000 .000 & 544.801 .075 \\
\hline & Total créditos tercera clase & & 700.000 .000 & 544.801 .075 \\
\hline
\end{tabular}

El Banco del Empresario pertenece, en concordancia con en el artículo 2499 del Código civil en el cual se comprenden los créditos hipotecarios, a la hipoteca que se tenía sobre el inmueble de la empresa se le otorga este grado. 


\section{CUARTA CLASE}

\section{QUINTA CLASE}

De acuerdo con el artículo 2509 del Código civil pertenecen a esta categoría los siguientes créditos:

\begin{tabular}{|l|l|l|l|l|}
\hline No. & \multicolumn{1}{|c|}{ ACREEDOR } & \multicolumn{1}{c|}{$\begin{array}{c}\text { APODERADO O } \\
\text { REPRESENTANTE }\end{array}$} & \multicolumn{1}{c|}{$\begin{array}{c}\text { CUANTÍA } \\
\text { SOLICITADA }\end{array}$} & MONTO A PAGAR \\
\hline 1 & BANCO DEL COMERCIANTE & $\begin{array}{l}\text { María Alejandra Cardona } \\
\text { María Alejandra Guerrero }\end{array}$ & 120.000 .000 & 0 \\
\hline 3 & SEGUROS UNVERSAL & $\begin{array}{l}\text { Alejandro Torres } \\
\text { María Paula Macías }\end{array}$ & 80.000 .000 & 0 \\
\hline 8 & PERSONAS NATURALES & $\begin{array}{l}\text { Juan Felipe Robledo } \\
\text { María Solano }\end{array}$ & 200.000 .000 & 0 \\
\hline 10 & LEASING EMPRESARIAL & $\begin{array}{l}\text { Daniel Pinzón } \\
\text { Federico Lewin }\end{array}$ & 400.000 .00 & 0 \\
\hline 6 & $\begin{array}{l}\text { EMPRESAS PRESTADORAS DE } \\
\text { SERVICIOS PÚBLICOS }\end{array}$ & $\begin{array}{l}\text { Luis Rojas } \\
\text { Andrés Alaix }\end{array}$ & 300.000 .000 & 0 \\
\hline & Total créditos de quinta clase & & 1.100 .000 .000 & 0 \\
\hline
\end{tabular}


Al igual que los créditos de la clase anterior, la suma de activos a repartir, según la graduación de los créditos, no fue suficiente para asignar indemnizaciones a los créditos de esta categoría.

\section{RESUELVE}

PRIMERO: TENER POR RECONOCIDOS Y ADMITIDOS los créditos relacionados en este auto, en las cuantías y en los grados allí indicados, a cargo de la sociedad CREACIONES MODERNAS LTDA. EN LIQUIDACIÓN JUDICIAL.
SEGUNDO:

REALIZAR EL PAGO de los créditos acorde con lo establecido en el auto, teniendo en cuenta las cuantías que fueron asignadas a cada uno de estos.

\section{NOTIFÍQUESE Y CÚMPLASE}

Los superintendentes,

Daniel Pinzón

Federico Lewin 